\title{
SEYFE GÖLÜ SULAK ALAN HAVZASINDAKİ SU KAYNAKLARININ DURAYLI İZOTOP İÇERIKLERINIIN İNCELENMESİ
}

\author{
Cansu YURTERI
}

Hacettepe Üniversitesi, Mühendislik Fakültesi, Jeoloji (Hidrojeoloji) Mühendisliği Bölümü, Ankara, Türkiye

\begin{tabular}{|c|c|}
\hline Anahtar Kelimeler & Öz \\
\hline $\begin{array}{l}\text { Hidrojeoloji, } \\
\text { Döteryum, } \\
\text { Oksijen-18, } \\
\text { Seyfe Gölü Havzası, } \\
\text { Sulak Alan. }\end{array}$ & $\begin{array}{l}\text { Duraylı izotop teknikleri hidrojeolojik süreçlerin anlaşılmasında ve hidrodinamik } \\
\text { yapının kavramsallaştırılmasında önemli katkılar sağlamaktadır. Bu çalışmada } \\
\text { Seyfe Gölü havzasındaki su kaynaklarının geçirdikleri fiziksel ve kimyasal süreçlerin } \\
\text { açıklanması amacıyla duraylı izotop içerikleri değerlendirilmiştir. Çalışma alanı } \\
\text { Kırşehir ilinin kuzeydoğusunda yer alan } 1447 \mathrm{~km}^{2} \text { 'lik yüzey drenaj alanına sahip } \\
\text { Seyfe Gölü havzasını kapsamaktadır. Havza içerisinde Paleozoyik yaşlı Kırşehir } \\
\text { Masifi metamorfik serileri, Senozoyik yaşlı örtü birimler ve Kuvaterner yaşlı } \\
\text { alüvyon birimler yüzeylemektedir. Paleozoyik yaşlı Kırşehir Masifinin Bozçaldağ } \\
\text { Formasyonu'nu temsil eden mermer ve kireçtaşı seviyelerinin kırıklı ve çatlaklı } \\
\text { zonları akifer özelliği göstermektedir. Eylül } 2019 \text { ve Aralık } 2019 \text { 'da havza drenaj } \\
\text { alanında yer alan kaynaklardan, sığ kuyulardan ve drenaj kanalından Oksijen-18 ve } \\
\text { Döteryum analizleri için örneklemeler yapılmıştır. Çalışma alanındaki su } \\
\text { noktalarının } \delta^{18} 0 \text { değerleri \%o-11.97 ile -\%o3.29 VSMOW arasında; } \delta^{2} \mathrm{H} \text { değerleri ise } \\
\text { \%o -80.88 ile \%o-27.61 VSMOW arasında değişmektedir. Havzanın kuzeybatısında } \\
\text { metamorfik birimlerden beslendiği düşünülen su kaynaklarının beslenme alanları } \\
\text { diğer su kaynaklarına göre daha yüksek kotlarda bulunmaktadır. Göl alanına ve } \\
\text { drenaj kanallarına yakın olan bazı su noktalarında ise buharlaşma etkisi } \\
\text { görülmektedir. }\end{array}$ \\
\hline
\end{tabular}

\section{INVESTIGATION OF STABLE ISOTOPE CONTENTS OF WATER RESOURCES IN SEYFE LAKE WETLAND BASIN}

\begin{tabular}{l}
\hline Keywords \\
\hline Hydrogeology, \\
Deuterium, \\
Oxygen-18, \\
Seyfe Lake Basin, \\
Wetland.
\end{tabular}

Wetland. \begin{abstract}
Stable isotopes techniques make a significant contributions to the understanding of hydrogeological processes and the conceptualization of the hydrodynamic structure. In order to explain the physical and chemical processes regarding the water resources of Seyfe Lake basin, results of stable isotope analysis of the waters are evaluated in the study. The study area covers the entire basin of Seyfe Lake basin which has a catchment area of $1447 \mathrm{~km}^{2}$ and is located northeast of Kirsehir. Paleozoic Kirsehir Massif metamorphic series, Cenozoic cover units and Quaternary alluvial units are exposed in the basin. The fractured and faulted zones of the marble and limestone levels representing the Bozçaldağ Formation of the Paleozoic Kirsehir Massif show aquifer characteristics. In September 2019 and December 2019, water samples from springs, shallow wells and drainage channel were collected in the catchment area for Oxygen-18 and Deuterium isotope analysis. In the study area; $\delta^{18} \mathrm{O}$ value of the water samples varies between $\% 0-11.97$ and $\% 0-3.29$ VSMOW; and $\delta^{2} \mathrm{H}$ value changes between \%o -80.88 and \%o -27.61 VSMOW. The recharge area of the springs thought to be recharged from the outcrops of the metamorphic units are located at northwest of the basin and higher in altitude than the other water resources. Some of the sampling points near the lake area and the drainage channels exhibit isotopic enrichment due to evaporation.
\end{abstract}

Alıntı / Cite

Yurteri, C., (2020). Seyfe Gölü Sulak Alan Havzasındaki Su Kaynaklarının Duraylı İzotop İçeriklerinin İncelenmesi, Mühendislik Bilimleri ve Tasarım Dergisi, 8(3), 883-903.

\footnotetext{
* ilgili yazar / Corresponding author : cyurteri@hacettepe.edu.tr, +90-312-297-77-00 /169
} 


\begin{tabular}{l|l|l}
\hline Yazar Kimliği / Author ID (ORCID Number) & \multicolumn{3}{|l}{ Makale Süreci / Article Process } \\
\hline C.Yurteri, 0000-0002-4944-0168 & Başvuru Tarihi / Submission Date & 15.07 .2020 \\
& Revizyon Tarihi / Revision Date & 08.09 .2020 \\
& Kabul Tarihi / Accepted Date & 11.09 .2020 \\
& Yayım Tarihi / Published Date & 24.09 .2020 \\
\hline
\end{tabular}

\section{Giriș (Introduction)}

Günümüzde su kaynaklarına duyulan ihtiyaç gittikçe artmaktadır. Buna karşıllk doğal (iklimsel) ve antropojenik (kuyularla aşırı yeraltısuyu çekimi, kirlilik vb.) nedenlerle su kaynaklarındaki azalmanın devam ettiği görülmektedir. Ülkemizde artan su ihtiyacının karşılanmasında sulak alanlar önemli su kütleleri olarak yer tutmaktadır. Sulak alanlardaki su kaynakları potansiyelinin değerlendirilmesi için gerçekleştirilecek hidrojeolojik çalışmaların, sulak alanın bağlı olduğu havza ölçeğinde gerçekleştirilmesi uygun olacaktır.

Hidrojeolojide duraylı izotop uygulamaları, havza ölçekli gerçekleştirilen çalışmalarda yaygın olarak kullanılmaktadır. Ayrıca yeraltı ve yerüstü su kaynaklarının etkin korunması ve sürdürülebilirliği için sistemin mevcut hidrodinamik yapısının tanımlanmasında duraylı izotop tekniklerinden yararlanılmaktadır.

Duraylı (Oksijen-18, Döteryum) izotoplar hidrolojik çevrim içerisinde ölçülebilir miktarlarda yer almaktadırlar (Clark ve Fritz, 1997). Dolayısıyla suyun iyi birer izleyicileridirler ve ayrıntılı bilgiler sağlamaktadırlar (Gat ve Gonfiantini, 1981). Bu tür izotoplar akiferlerin beslenme alanlarının belirlenmesi, farklı kökenli suların ayırt edilmesi, geçirilen kimyasal ve fiziksel süreçlerin belirlenmesi ve yeraltısuyu-yüzeysuyu ilişkisi ile ilgili değerlendirmelere olanak sağlamaktadırlar (Gat ve Gonfiantini, 1981). Ayrıca kavramsal hidrojeolojik modellerin oluşturulmasında yaygın bir şekilde kullanılan yardımcı tekniklerdir.

Bu çalışmada, Türkiye'nin önemli sulak alan havzalarından biri olan Seyfe Gölü havzasındaki su kaynaklarının duraylı izotop içerikleri incelenmiştir. Bu kapsamda havzadaki su noktalarının beslenim alanı yükseltilerinin hesaplanması, farklı kökenli suların ayırt edilmesi ve geçirilen hidrojeolojik süreçlerin açıklanmasına yönelik değerlendirmeler araştırmanın amacını oluşturmaktadır.

Literatürde; çalışma alanında havza ölçeğinde izotop hidrojeolojisine yönelik sınırlı sayıda çalışma mevcuttur. Bilimsel yazın araştırmasına göre araştırma konusuyla ilgili çalışmalara; (Ünsal, 1999; Çelik vd., 2008) örnekler verilebilir.

Çalışmada giriş bölümünden sonra alandaki bilimsel yazın araştırması sonuçları verilecek, havzada uygulanan materyal ve yöntem açıklandıktan sonra araştırma bulguları sunulacaktır. En son olarak sonuç ve tartışma kısmı ile çalışma tamamlanacaktır.

\section{Bilimsel Yazın Araștırması (Literature Survey)}

Geçmişten günümüze kadar çalışma alanı ve yakın çevresinin jeolojik, hidrojeolojik, hidrolojik ve jeomorfolojik yapısının tanımlanmasına yönelik çeşitli disiplinlerde çalışmalar gerçekleștirilmiştir. Literatürde yer alan çalışmalar, çalışma yılı sırasına göre verilmiştir.

Erguvanlı (1957), “Kırşehir Kuzeyinde Seyfe Ovasının Hidrojeolojik Etüdü” isimli çalışmasında Seyfe ovasında jeolojik ve hidrojeolojik çalışmalar yürütmüştür. Bu kapsamda Seyfe Ovasının kuzeybatı-güneydoğu uzanımlı kapalı bir havza olduğu, havza drenaj alanının $1538 \mathrm{~km}^{2}$ olarak hesaplandığı ve bütün akışın ovanın en düşük kotu olan Seyfe Gölü'ne doğru yönlendiği belirtilmiștir.

Önhon (1969), "Seyfe Ovası Kristalize Kalker Sahasının Karst Etüdü ve Seyfe Kaynağının Geliștirilmesi” isimli çalışmasında Seyfe kaynağının geliştirilmesine yönelik çalışmalar gerçekleştirmiştir. Mart 1969 ile Nisan 1970 dönemi arasında yapılan gözlemler sonucu; Seyfe kaynağının hacmi $26^{*} 10^{6} \mathrm{~m}^{3} / \mathrm{yll}$ olarak hesaplanmıștır. Kaynaktan yıllık $18^{*} 10^{6} \mathrm{~m}^{3}$ boşalım gerçekleștiği ve yıllık $8^{*} 10^{6} \mathrm{~m}^{3}$ suyun rezervde kaldığı belirtilmiștir.

DSI (1975), "Kırşehir Seyfe Ovası Planlama Kademesi Jeofizik Rezistivite Etüd Raporu" isimli çalışmada Seyfe ovasında jeofizik çalışmaları yapılmıştır. Yapılan çalışmada en önemli kırık hatlarının Seyfe-Eskidoğanlı uzanımlı faylar ile Boztepe-Çimeli yönündeki faylar olduğu belirtilmiştir. Boztepe-Çimeli fayının doğuya doğru olan devam eden kesiminin Yazıkınık-Kızıldağyeniyapan-Büyükburunağıl'a kadar uzandığı belirtilmiştir.

DSI (1979), "Kırşehir-Seyfe Ovası Hidrojeolojik Etüd Raporu” isimli çalışmada Seyfe ovasının genel hidrolojik ve hidrojeolojik özellikleri açılanmış, Seyfe ovasındaki akiferlerin beslenim-boşalım ilişkileri ile yeraltısuyunun 
miktar ve kalitesi ortaya konulmaya çalışılmıştır. Yıllık beslenim miktarı $11 \times 10^{6} \mathrm{~m}^{3} / \mathrm{yll}$ olarak hesaplanmıştır. Bu miktarın \%70'i emniyetli verim alınarak, emniyetli verim $8 \times 10^{6} \mathrm{~m}^{3} / \mathrm{yll}$ olarak hesaplanmıștır.

Yiğitbaşığlu (1993), "Seyfe Gölü ve çevresinin jeomorfolojisi" konulu doktora tez çalışmasında; Seyfe Gölü'nün geniş, sı̆̆ ve tuzlu bir göl olduğu, göl ve çevresinin yarıkurak iklim özelliklere sahip olduğu, gölün başlıca beslenmesinin kaynak suları ve dipten beslenme yoluyla olduğu belirtilmiştir.

Ünsal (1999), "Seyfe Ovası kaynaklarının kimyasal ve izotopik bileşenleri ve kökeni" isimli çalışmasında Seyfe ovasındaki yeraltısularının jeokimyasal ve izotopik özellikleri ile kökensel araştırılması gerçekleştirilmiştir. Yapılan incelemeler ile yeraltısularının geçiş sürelerinin trityum değerlerine göre; 1-3 yıl arasında değiştiği ve yeraltısularının genellikle Bozçaldağ Formasyonundaki kireçtaşı birimlerinden beslendiği belirtilmiştir.

Sayhan (2000), "Seyfe Havzasının Jeomorfolojisi (Kırşehir)" isimli çalışmasında alanla ilgili jeolojik ve jeomorfolojik çalışmalar gerçekleștirmiştir. Yapılan çalışmalar ile Seyfe havzasının kapalı bir havza olduğu, dışarıya akışın mevcut olmadığı, bölgede yarı-kurak iklim şartlarının egemen olduğu, alandaki morfolojik yapıların iklim koşulları ile uyumlu olarak geliştiği ve bölgenin tipik bir yarı-kurak bir bölge topografyasına sahip olduğu belirtilmiştir.

Sayhan (2001), "Seyfe Gölü Eski Seviyelerinin Kuvaterner Jeomorfolojisi Açısından Etüdü" isimli çalışmasında, son 24.000 yılda Seyfe Gölü’nde önemli seviye değişimleri olduğunu; Eski Seyfe Gölü’ndeki su seviyesi değişimlerine bağlı olarak Seyfe Havzası'nın dış drenajdan koptuğunu, serin, nemli dönemlerde gölün su seviyesinin yükseldiğini, sıcak-kurak dönemlerde gölün su seviyesinin düştüğünü ve göl seviyesinin 1110 metrede olduğu belirtilmiştir.

DSI (2004), "Seyfe Ovası Hidrojeolojik Revize Etüt Raporu" isimli çalışmada 1979 yılında hazırlanan "KırşehirSeyfe Ovası Hidrojeolojik Etüt Raporu'nun revize edilmesi amaciyla, Seyfe Ovasında 2001-2003 yılları arasında arazi çalıșmaları yapılmıștır. Yapılan incelemeler ile, Seyfe kapalı havzasının yüzey suyu drenaj alanı $1430 \mathrm{~km}^{2} \mathrm{ve}$ akifer alanı $150 \mathrm{~km}^{2}$ olarak belirlenmiştir. Havza boşalımının Seyfe Gölü'ne doğru olduğu belirlenmiştir. Ovada açılmış olan kuyuların statik su seviyeleri, 1 ile $57 \mathrm{~m}$; kuyu verimleri 10 ile 40 l/s ; özgül debileri 1 ile $10 \mathrm{l} / \mathrm{s} / \mathrm{m}$; hidrolik iletkenlik katsayısının ise 140 ile $4700 \mathrm{~m}^{3} /$ gün/m arasında değiştiği belirtilmiștir.

Tüfenkçi (2005), "Seyfe Kaynağı ve Dolayının (Kırşehir) Hidrojeoloji İncelemesi" konulu yüksek lisans tez çalışmasında Kırşehir-Seyfe kaynağı ve çevresindeki yeraltı sularının fasiyesleri, fasiyeslerin birbirleriyle ilişkileri ve kalitesi belirlenmiș, geleceğe yönelik su kullanımı ile ilgili tahminlerde bulunulmuştur. Bölgede yapılan çalışmalar kapsamında Paleozoyik yaşlı Bozçaldağ Formasyonu içerisindeki mermer birimlerin yeraltı suyu taşıyan birimler olduğu, suların Ca- $\mathrm{HCO}_{3}$ ve $\mathrm{Ca}-\mathrm{Mg}-\mathrm{HCO}_{3}$ fasiyesindeki sular olduğu belirtilmiştir.

Yılmaz ve Reis (2008), “Seyfe Gölü’nün Zamansal Değișiminin Uzaktan Algılama Tekniği ile İzlenmesi” isimli çalışmalarında, Seyfe Gölü ve çevresinde zamana bağlı olarak meydana gelen su yüzey alanındaki değiş̧imler incelenmiștir. Bu kapsamda göldeki 1975-2001 yılları arasındaki zamansal değişimin, meteorolojik verilerle de karşılaştırılması sonucunda gölün su yüzey alanının 1975 yılı Ağustos ayında 2021,3 Ha, 1987 yllı Haziran ayında 6562,6 Ha ve 2001 yılı Mayıs ayında 2182,7 Ha olarak hesaplanmıștır. Gölün su rezervinde zamana bağlı bir azalmanın gerçekleştiği belirtilmiştir.

Çelik vd (2008), "Seyfe Gölü (Kırşehir-Türkiye) Havzası'nın Su Kalitesi ve Kirlilik Değerlendirilmesi” isimli çalışmalarında Seyfe Gölü Havzasında yer alan yüzey ve yeraltısuları ile ilgili hidrojeokimyasal ve izotopik değerlendirmeler yapılmıştır. Yapılan değerlendirmelere göre; çalışma alanındaki yeraltısularını temsil eden su noktalarının Küresel Meteorik Su Doğrusu üzerinde yer aldığı, bu suların meteorik kökenli olduğu, sı̆̆ kuyulardan ve drenaj kanallarından örneklenen sularda ise buharlaşma etkisinin görüldüğü belirtilmiştir.

MTA (2009), "Kırșehir-Mucur-Seyfe Gölü Havzası Maden Jeolojisi Raporu” isimli çalıșmada Seyfe Gölü çevresindeki çökellerde, su bölüm hattı içerisinde kalan jeolojik birimlerde ve göl alanında incelemeler gerçekleștirilmiștir. Yapılan araştırmalar ile göl suyundaki sodyum ve klorür iyon değerlerinin yüksek düzeylerde, sülfat ve potasyum içeriklerinin de önemli miktarlarda olduğu belirtilmiştir.

Kıymaz vd (2011), "Standartlaştırılmış Yağıș İndeksi ile Seyfe Gölünün Kuraklık Dönemlerinin Belirlenmesi” isimli çalışmalarında Seyfe Gölü'nün geçmiş yıllarda düşen yağış miktarına bağlı olarak meteorolojik kuraklık incelenmiştir. Bu kapsamda, Standartlaştırılmış Yağış İndeksi (SPI) yöntemi kullanılarak dönemsel kuraklık değerlerinin birbirlerinden farklı olduğu belirlenmiş, bu değerlerin Kırşehir ilinin gelecek yıllarda su stresini arttıracağı belirtilmiștir. Bu kapsamda gerekli kuraklık önlemlerinin alınmasının önemli olacağı vurgulanmıştır. 
Çiftçi (2013), "Seyfe Gölü Havzası'nda (Kırşehir) Doğal Ortam-Yeraltısuyu İlişkisi” isimli yüksek lisans tez çalışmasında; Türkiye'nin 12 sulak alanından biri olan Seyfe Gölü ve çevresinin doğal ortam özellikleri ve hidrojeolojik özellikleri incelenmiştir. Seyfe Göl alanının çeşitli noktalarından örneklenen su noktalarının pH değerlerinin 8 ile 9.13 arasında değiştiği ve suların bazik özellik gösterdiği belirtilmiştir.

Kıymaz ve Karadavut (2014), "Seyfe Gölü Havzasında yer alan Kuyuların Sularının Sulama Suyu Kalitesi Açısından Değerlendirilmesi” isimli çalışmalarında Seyfe Gölü Havzasında yer alan su kuyularından 2008-2009 yıllarının Haziran ve Eylül dönemlerinde örneklemeler gerçekleştirilmiştir. Yapılan çalışmada; örneklenen yeraltısularının sulama suyu kalitesi açısından izin verilen değerlerden daha yüksek olması nedeniyle sulama suyu olarak kullanılamadığı tespit edilmiştir

Literatürde çalışma alanında duraylı izotop hidrojeolojisi kullanılarak havza ölçeğinde izotopik karakterizasyona yönelik çok az sayıda çalışmanın olduğu görülmektedir. Ayrıca literatürde havza ölçeğinde duraylı izotop tekniklerinden yararlanarak su kaynaklarının izotop içeriklerinin oransal değişimi ve beslenim alanı yükseltisi hesaplamaya yönelik bir çalışma yapılmamıștır. Dolayısıyla bu çalışmada Türkiye'nin önemli sulak alan havzalarından biri olan Seyfe Gölü sulak alan havzasındaki su noktalarının izotop içeriklerinin oransal değişimi, beslenim alanı yükselti hesaplamaları, farklı kökenli suların ayırtedilmesi ile geçirilen fiziksel ve kimyasal süreçleri açıklamaya yönelik değerlendirmeler yapılmıştır.

\section{Materyal ve Yöntem (Material and Method)}

\section{1. Çalışma Alanı (Study Area)}

Kızılırmak Havzası'nın alt havzalarından biri olan Seyfe Gölü Havzası, ortalama deniz seviyesinden 1110 metre yükseklikte kapalı bir havzadır. Çalışma alanının kuzeybatısı, güneybatısı ve batısı yüksek dağlar ve tepelerle, doğu tarafı ise alanın batısına göre yükseltileri fazla olmayan tepelerle çevrilidir. Yükseltilerin $950 \mathrm{~m}$ ile $1706 \mathrm{~m}$ kotları arasında değiștiği havzada; inceleme alanı içerisindeki en önemli yükseltileri Hamurlubeșler Tepe, Bozdağ, Ayrıdağ ve Kervansaray Dağ olușturmaktadır. Havzaya ismini veren Seyfe Gölü; Kırșehir ili sınırları içerisinde

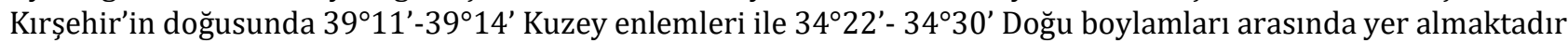
(Şekil 1).

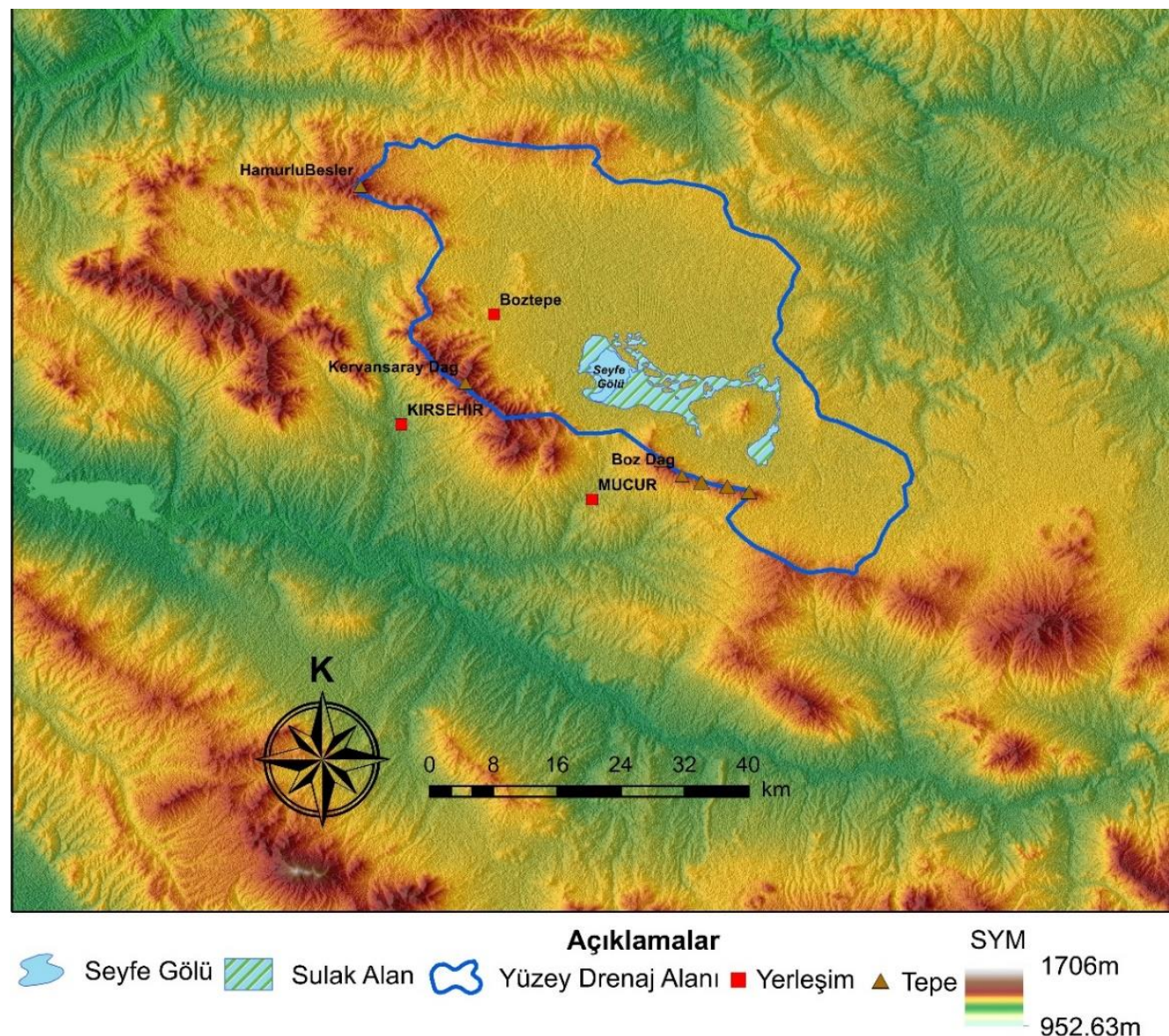

Şekil 1. Çalıșma alanının yer bulduru haritası (Location map of the study area) 
Havzanın uzanımı kuzeybatı güneydoğu yönündedir. İnceleme alanında genellikle yazların sıcak ve kurak, kışların soğuk geçtiği karasal iklim koşulları hakimdir. Gece ile gündüz, yaz ile kış arasındaki sıcaklık farkları yüksektir. Çalışma alanına en yakın istasyon olan Kırşehir Meteoroloji Gözlem İstasyonu'nun (MGí) verilerine göre 19302019 yılları arasında yıllık ortalama yağış miktarı $384.5 \mathrm{~mm}$, yıllık ortalama sıcaklık ise $11.51^{\circ} \mathrm{C}$ 'dir. Bölgede aylık en düșük ortalama sıcaklık $-0.22{ }^{\circ} \mathrm{C}$ ile Ocak ayında; aylık en yüksek ortalama sıcaklık ise $23.09{ }^{\circ} \mathrm{C}$ ile Temmuz ayında ölçülmüştür. Havzada 1996-2019 yılları arasında hakim rüzgar yönü Kuzeydir.

\section{2. Örnekleme ve Analiz Yöntemi (Sampling and Analysis Method)}

Seyfe Gölü havzası yüzey drenaj alanı içerisinde yer alan yerüstü ve yeraltı su kaynaklarının kökenlerinin belirlenmesi, havzadaki akiferlerin beslenme alanı yükseltilerinin hesaplanması, farklı kökenli suların ayırtlanması ile su-kayaç etkileşimi gibi hidrojeolojik süreçleri açıklamak amacıyla duraylı izotop örnekleme çalışmaları gerçekleștirilmiştir. Eylül 2019 ve Aralık 2019 dönemlerinde Seyfe Gölü havzasının yüzey drenaj alanı içerisinde belirlenen 40 su noktasından (kaynaklar, kuyular, dere ve kar) yerinde ölçüm ve duraylı izotop örneklemeleri gerçekleştirilmiştir.

Çalışma alanındaki su noktalarının beslenim ve boşalım ilişkilerinin yorumlanması için yüzey drenaj alanında yer alan doğal kaynak boşalımları örnekleme noktası olarak tercih edilmiştir. Bu kaynakların boşalım noktalarına yakın veya litolojik birimleri doğrudan boşaltıyor olması göz önünde bulundurulmuştur. Ayrıca örnekleme noktaları havzadaki jeolojik birimleri temsil edecek şekilde seçilmiştir. Kuyu örneklemelerinde ise kuyulardaki filtrelenmiş kısımların farklı akifer birimleri temsil ediyor olmasına dikkat edilmiştir.

Yapılan yerinde ölçümlerde suların pH, sıcaklık (T), özgül elektriksel iletkenlik (ÖEİ- $\left.25^{\circ} \mathrm{C} / \mu \mathrm{S}-\mathrm{cm}\right)$ ve çözünmüş oksijen (ÇO) gibi fizikokimyasal özellikleri Hanna marka taşınabilir çok parametreli su kalitesi ölçüm cihazı ile ölçülmüştür. Duraylı izotop örnekleme çalışmaları arazide yerinde gerçekleştirilmiş ve su örnekleri 60 ml' lik polietilen şişeler içerisine hava kalmayacak şekilde alınarak serin yerde muhafaza edilmiş ve laboratuvara ulaştırılmıştır.

Havza ölçeğinde örneklenen yerüstü ve yeraltı su kaynaklarının duraylı izotop analizleri Hacettepe Üniversitesi Uluslararası Karst Su Kaynakları Uygulama ve Araştırma Merkezi (UKAM) Duraylı İzotop Laboratuvarı'nda gerçekleștirilmiștir. Örneklerin duraylı izotop içerikleri Los Gatos Research (LGR) Liquid Isotopic Water Analyzer cihazı kullanılarak analiz edilmiştir. Analiz sonuçları Viyana Standart Ortalama Okyanus Suyu (VSMOW) ölçeğine göre normalize edilmiştir. Döteryum ve Oksijen-18 izotoplarının oranı Standart Ortalama Okyanus suyundan binde sapma $(\delta)$ olarak verilmiştir. $\delta^{18} \mathrm{O}$ ve $\delta^{2} \mathrm{H}$ analizlerinin ortalama hata payl ${ }^{2} \mathrm{H}$ için $\pm \% 00,41-0.59$ VSMOW; ${ }^{18} \mathrm{O}$ için $\pm \%$ 0.07-0.08 VSMOW düzeyindedir.

\section{Araştırma Bulguları (Research Findings)}

\section{1. Çalışma Alanının Jeolojisi (Geological Outline of the Study Area)}

Çalışma alanının jeolojisi Seyfe Gölü havzası yüzey drenaj alanı içerisinde yüzeyleyen litolojik birimler temel alınarak incelenmiștir. Buna göre havzada Paleozoyik yaşlı Kırşehir Masifi metamorfitleri, Üst Eosen ve MiyosenPliyosen yaşlı sedimanter birimler ile Kuvaterner yaşlı alüvyon birimler yüzeylemektedir. Çalışma alanının jeolojisi ve litolojik birimlerin stratigrafisi geçmişte yapılan jeolojik haritalama çalışmaları (MTA, 1991; MTA, 1992) temel alınarak verilmiştir (Şekil 2).

Çalışma alanının temelini litostatigrafik olarak Paleozoyik yaşlı Kalkanlıdağ, Kervansaraydağ ve Bozçaldağ Formasyonları oluşturmaktadır. Havzada metamorfik temelin tabanı görülmezken metamorfik temel kalınlığı $1000 \mathrm{~m}$ ile $2000 \mathrm{~m}$ arasında değişmektedir (MTA, 2009).

Kırşehir Masifinin alt seviyelerini oluşturan Kalkanlıdağ Formasyonu magmatik kökenli kayaçların metamorfizmasıyla oluşmuştur. Birim amfibolit şist, kuvarsit șist, biyotit-muskovit şist, kalk sişt, granitik gnays, gözlü gnays ve biyotit-muskovit gnaysdan oluşmaktadır (MTA, 2009). Formasyon Seyfe Gölü havzasının batı ve kuzeybatısında geniş yüzlekler vermektedir. Bu birim Paleozoyik yaşlı Kervansaraydağ Formasyonu ve Bozçaldağ Formasyonu tarafindan üzerlenmektedir (MTA, 1991). Birim üste doğru Kervansaraydağ Formasyonu ile geçişlidir (MTA, 1991). Kervansaraydağ Formasyonu; biyotit-muskovit şist, piroksen şist, amfibol şist ve daha az miktarda klorit şist, talk şist, gnays ile mermer bant ve merceklerinden oluşmaktadır (DSİ, 2004). Kıvrımlanma ve yapraklanmanın oldukça iyi geliştiği formasyon, havza batısında Boztepe yakınlarında yüzlekler vermektedir. Birim kendisini üzerleyen Bozçaldağ Formasyonu ile düşey ve yanal yönde geçişlidir (DSİ, 2004). 


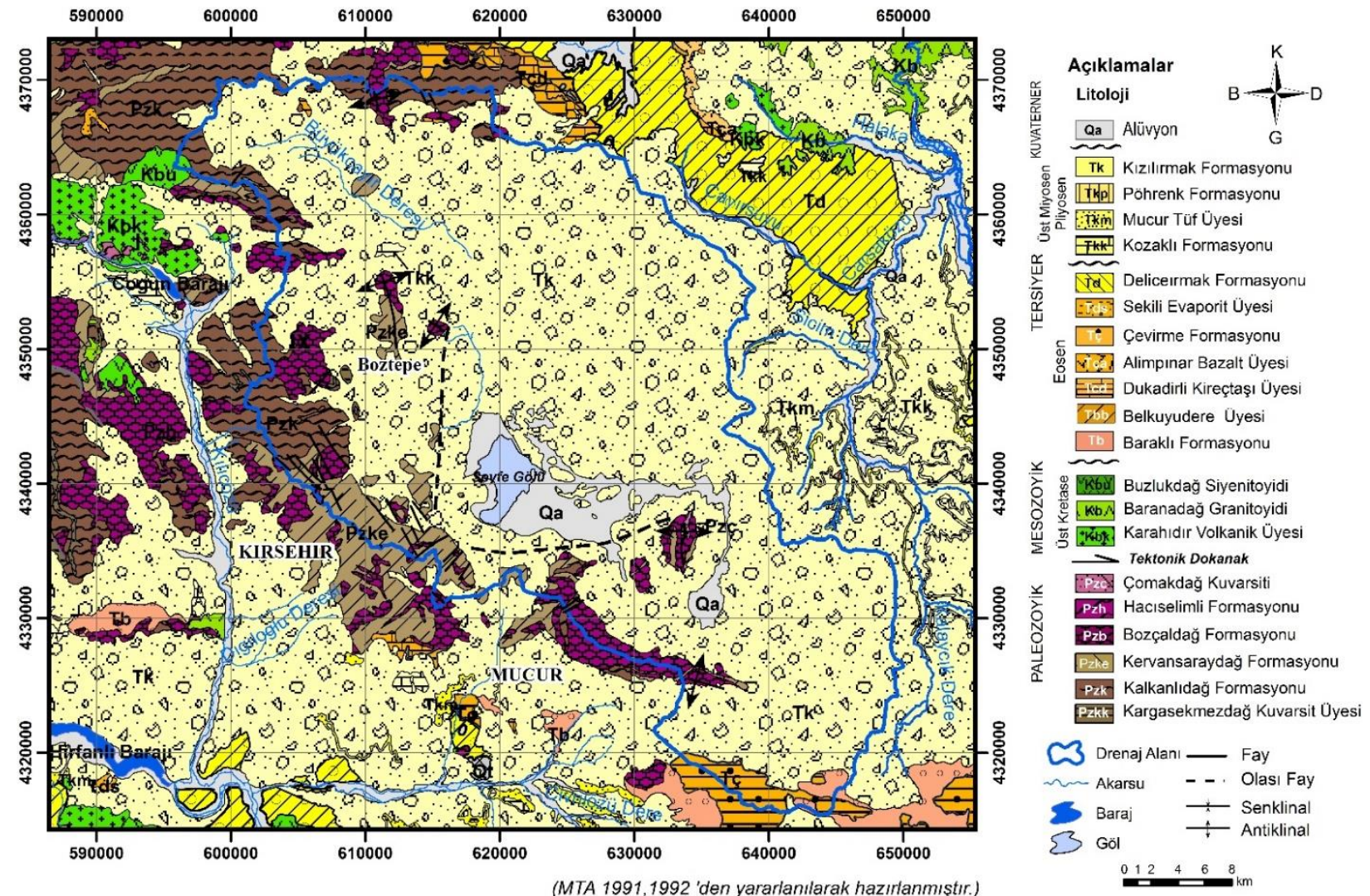

Şekil 2. Çalışma alanı ve yakın çevresinin jeoloji haritası (Geological map of the study area and its surroundings)

Bozçaldağ Formasyonu ise masif yapılı, kırıklı-çatlaklı, iri kristalli, şeker dokulu, gri beyaz renkli orta-kalın tabakalı mermerlerden oluşmaktadır (MTA, 2009). Birim Seyfe Gölü havzasının güneyinde ve kuzeyinde Göllü, Çimeli, Boztepe, Karacaören, Gümüşkümbet köylerinde parçalı bloklar halinde kristalize kireçtaşları ile mermer seviyelerden oluşan yüzlekler vermektedir. Paleozoyik metamorfik temeli oluşturan Kalkanlıdağ, Kervansaraydağ ve Bozçaldağ Formasyonları; Tersiyer yaşlı sedimanter birimler tarafından açısal uyumsuzlukla üzerlenmektedir (MTA, 2009).

Tersiyer yaşlı birimler havzada Üst Eosen ve Miyosen-Pliyosen yaşlı birimler ile temsil edilmekte ve geniş bir alanda yüzeylemektedirler. Havzada Üst Eosen; Baraklı Formasyonu ve Çevirme Formasyonu ile temsil edilmektedir. Baraklı Formasyonu havzanın güneydoğusunda İlicek köyü yakınlarında çok sınırlı bir alanda yüzeyleyen, kırmızı kahve renkli tutturulmamış, gevşek kumtaşı, çakıltaşı ve çamurtaşlarından oluşmaktadır (Seymen, 1982). Birim üste doğru Çevirme Formasyonu ile yanal ve düşey yönde geçişlidir. Birim kalınlığ $100 \mathrm{~m}$ ile $700 \mathrm{~m}$ arasında değişmektedir (MTA, 2009). Çevirme Formasyonu ise çakıltaşı, kumtaşı, silttaşı, çamurtaşı, kiltaşı ve marn birimlerinden oluşmaktadır (DSİ, 2004). Bu birim Seyfe Gölü havzasının güneydoğusunda Yeniyapan köyü yakınlarında yüzlek vermektedir. Birim kalınlığı $200 \mathrm{~m}$ ile $250 \mathrm{~m}$ arasında değişmektedir (DSi், 2004).

Çevirme ve Baraklı Formasyonlarının üzerine Üst Miyosen-Pliyosen yaşlı Kızılırmak Formasyonu açısal uyumsuzlukla gelmektedir. Kızılırmak Formasyonu havza içerisinde çok geniş bir topografyada yüzeylemekte ve Paleozoyik temeli örtmektedir. Birim kızıl renkli çakıltaşı, kumtaşı, çamurtaşı, kiltaşı, marn, gölsel kireçtaşı ve jips seviyelerinin ardalanmasından oluşmaktadır (DSİ, 1979).

Kızılırmak Formasyonu ise havzada en genç birim olan Kuvaterner yaşlı alüvyon birimler tarafından uyumsuzlukla örtülmektedir (MTA, 1991). Alüvyon birimler Seyfe köyü doğusunda ve Horla-Badıllı mevkiinde kumlu killi alüvyon ve çamurtaşlarıyla temsil edilmektedir. Birim kalınlığı 10 m ile 15 m arasında değişmektedir (DSİ, 1979).

\section{2. Çalışma Alanının Hidrojeolojisi (Hydrogeological Outline of the Study Area)}

Seyfe Gölü havzasındaki jeolojik birimlerin hidrojeolojik özellikleri belirlenmiş ve çalışma alanının hidrojeoloji haritası hazırlanmıştır (Şekil 3). Alanda yüzeyleyen litolojik birimler; suyu taşıma ve iletme özelliklerine göre geçirimli, geçirimsiz ve yarıgeçirimli birimler olarak üç ayrı grupta ayırtlanmış ve haritalanmıştır. Çalışma alanında yüzeyleyen hidrostratigrafik birimler aşağıda ayrıntılı olarak verilmiştir. 


\subsubsection{Geçirimli Birimler (Permeable Units)}

Kırşehir Masifi serileri içerisinde yer alan mermer seviyeler ve kristalen kireçtaşları havzadaki tektonik süreçlerin etkisi ile kırıklı ve çatlaklı bir yapı kazanmıștır. Dolayısıyla ikincil gözeneklilik kazanmıș Paleozoyik yaşlı mermer seviyelerin kırıklı, çatlaklı zonları yeraltısuyunu tașıması ve iletmesi nedeniyle akifer özelliği göstermektedir. Mermer birimler havzanın kuzeyinde, batısında ve güneyinde yüzeyde görülmektedir. Havza içerisinde kristalize kireçtaşı ve mermer akiferinin kalınlığı değişmektedir.

Havzada açılan DSİ kuyularının litolojik logları incelendiğinde; mermer ve kristalize kireçtaşı akiferinin kalınlığı Malya bölgesinde açılan kuyularda $26 \mathrm{~m}$ ile $68 \mathrm{~m}$ arasında, Boztepe bölgesinde açılan kuyularda $40 \mathrm{~m}$ ile $43 \mathrm{~m}$ arasında, Karacaören bölgesinde açılan kuyularda $40 \mathrm{~m}$, Eskidoğanlı bölgesinde açılan kuyularda $78 \mathrm{~m}$ ile $80 \mathrm{~m}$ arasında, Yenidoğanlı bölgesinde açılan kuyuda 60 m, Kızıldağyeniyapan bölgesinde açılan kuyuda 150 m, Göllü bölgesinde açılan kuyuda ise 100 m'dir (DSİ, 2004).

Paleozoyik yaşlı mermer ve kristalize kireçtaşları birimlerinde açılan kuyuların debileri $11.67 \mathrm{l} / \mathrm{s}$ ile $94.4 \mathrm{l} / \mathrm{s}$, iletimlilik değerleri 32 ile $4699 \mathrm{~m}^{2} /$ gün, özgül debileri ise 1.4 ile $45.8 \mathrm{l} / \mathrm{s} / \mathrm{m}$ arasında değişmektedir (DSİ, 2004). Havzanın Malya bölgesinde açılan 10766, 10768 ve 14219B numaralı DSİ kuyularının debileri havzanın diğer bölgelerindeki mermer ve kireçtaşı birimlerinde açılmış kuyulara göre daha yüksek verime sahiptir. Ortalama kuyu debileri ise $80 \mathrm{l} / \mathrm{s}$ ile $94.4 \mathrm{l} / \mathrm{s}$ arasında değişmektedir (DSİ, 2004). Havzadaki bazı kuyularda ise mermer seviyeler içerisinde şist bantları geçilmiştir. Mermer, şist ardalanmalı kuyularda ise kuyu verimlerinin daha düşük olduğu belirtilmiştir (DSİ, 2004).

Havzada Seyfe Gölü ve çevresinde yer alan ince kum, çakıl ve killerden oluşan, kalınlığı $10 \mathrm{~m}$ ile $15 \mathrm{~m}$ arasında değişen alüvyon birimler yer almaktadır. Havzada alüvyon birimlerin kalınlığının ve yayılımının fazla olduğu, bölge halkının keson kuyularla su alabildiği kesimlerde birincil gözeneklilik yüksek olup; birim geçirimli özelliktedir (Şekil 3). Ancak birimin kil içeren seviyelerinin kalınlaştığı kesimlerinin geçirimsiz özellikte olduğu düșünülmektedir.

Seyfe Göl alanı kapalı bir havza içerisinde bulunmaktadır. Havza genelinde yeraltısuyu akım yönü Seyfe Gölü'ne doğrudur. Göl alanına yakın kesimlerde açılan 858, 860, 861 ve 4093 numaralı kuyuların litolojik logları incelendiğinde; göl tabanında hidrojeolojik açıdan geçirimsiz Neojen yaşlı killi, marnlı ve çamurtaşı katmanlarından oluşan seviyelerin yer aldığı görülmektedir. Ayrıca kuyu debilerinin $0.4 \mathrm{l} / \mathrm{s}$ ile $2.4 \mathrm{l} / \mathrm{s}$ arasında değiştiği ve verimin düşük olduğu belirtilmiştir (DSİ, 2004). Dolayısıyla Seyfe Gölü tabanından yeraltısuyuna sızmanın gerçekleșmediği veya ihmal edilebilecek düzeyde olduğu düșünülmektedir.

\subsubsection{Yarıgeçirimli Birimler (Semipermeable Units)}

Çalışma alanında Kızılırmak Formasyonu'nun geçirimliliği değişkenlik göstermektedir. Kuyu logları incelendiğinde; birimde açılan kuyuların verimlerinin havzanın doğusunda ve batısında değiștiği görülmektedir. Kızılırmak Formasyonunda açılan sondaj kuyularının bir kısmından oldukça düşük verimler $(0.2-0.6 \mathrm{l} / \mathrm{s})$ elde edilirken; bazılarından ise görece daha yüksek verimler (2.5-3.4 l/s) alınabildiği görülmektedir. Kuyuların özgül debileri ise $0.01 \mathrm{l} / \mathrm{s} / \mathrm{m}$ ile $0.2 \mathrm{l} / \mathrm{s} / \mathrm{m}$ arasında değişmektedir (DSİ, 1979; DSİ, 2004). Düşük verim alınan kuyular genellikle havzanın doğusunda yer almaktadır. Bu kuyularda Kızılırmak Formasyonu'nun killi, siltli ve marnlı seviyeleri kesilmektedir. Formasyonun kireçtașı, kumtașı, çakıltașı seviyelerinin kesilmekte olduğu kuyulardan ise görece daha yüksek verimler alınabilmektedir (DSİ, 2004). Dolayısıyla havzada geniş bir topografyaya yayılmış olan Tersiyer yaşlı birimlerin kumtaşı-çakıltaşı ile killi kireçtaşı seviyeleri yarı geçirimli (akitard) özelliktedir (Şekil 3).

\subsubsection{Geçirimsiz Birimler (Impermeable Units)}

Çalışma alanındaki Paleozoyik yaşlı Kırşehir masifi metamorfik serilerine ait şist, kuvarsit, gnays ve amfibol şist gibi metamorfik kayaçlar ile yüzey drenaj alanı içerisinde sınırlı bir alanda yüzeyleyen Mesozoyik yaşlı granit, siyenit, granodiyorit gibi magmatik kayaçların kırıklı çatlaklı olmayan zonları yeraltısuyu taşımaması ve iletmemesi nedeniyle geçirimsiz (akifüj) özellik göstermektedir (Șekil 3). 


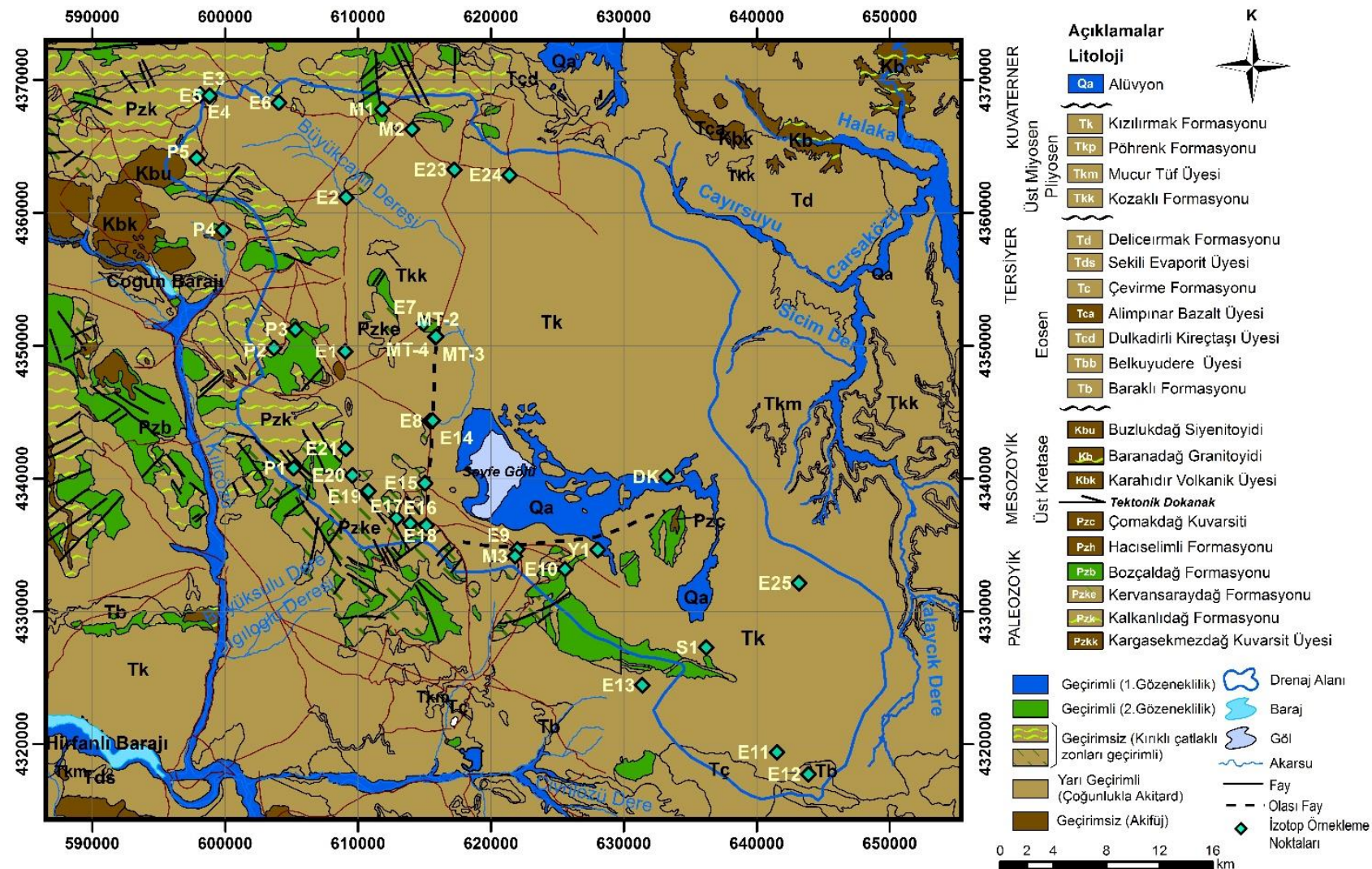

Şekil 3. Çalışma alanının hidrojeoloji haritası ve örnekleme noktaları (Hydrogeological map of the study area and the sampling points)

\subsection{Seyfe Gölü Havzasındaki Su Kaynaklarının Duraylı İzotop İçerikleri (Stable Isotope Contents of the Water Resources in the Seyfe Lake Basin)}

Eylül 2019 dönemi duraylı izotop analiz sonuçlarına göre örneklerin ortalama Oksijen-18 $\left(\delta^{18} 0\right)$ ve Döteryum $\left(\delta^{2} \mathrm{H}\right)$ içerikleri sırasıyla -10.04 VSMOW $(\% 0)$ ve -71.54 VSMOW $(\% 0)$ olarak ölçülmüştür. Eylül ayı izotop örneklemesinin en düşük Oksijen-18 $\left(\delta^{18} 0\right)$ içeriği -11.97 VSMOW (\%0) ile Paleozoyik yaşlı birimleri temsil eden P1 su noktası; en yüksek Oksijen-18 $\left(\delta^{18} 0\right)$ içeriği ise -0.86 VSMOW (\%o) değeri ile drenaj kanalını temsil eden DK su noktasıdır (Tablo 1).

Tablo 1. Çalışma alanında örneklenen su noktalarının duraylı izotop içerikleri, Eylül-2019 (Stable isotope contents of the water samples in the study area, September-2019)

\begin{tabular}{|c|c|c|c|}
\hline EYLÜL 2019 & $\boldsymbol{\delta}^{\mathbf{2}}$ (PERMIL) & $\boldsymbol{\delta}^{\mathbf{1 8}} \mathbf{0}$ (PERMIL) & YÜKSELTI (M) \\
\hline Minumum & -80.88 & -11.97 & 1108 \\
\hline Maksimum & -27.61 & -0.86 & 1370 \\
\hline Ortalama & -71.54 & -10.04 & 1187 \\
\hline
\end{tabular}

En yüksek Döteryum $\left(\delta^{2} \mathrm{H}\right)$ içeriği ise -27.61 VSMOW ile (\%o) DK su noktası; en düşük Döteryum $\left(\delta^{2} \mathrm{H}\right)$ içeriği ise 80.88 VSMOW (\%o) ile havzanın kuzeybatısındaki Paleozoyik yaşlı şist birimlerini temsil eden Hamurlubeşler yerleşim yerindeki P5 su noktasıdır (Tablo 1).

DK ve Y1 örnekleri açık yüzeyden sürekli buharlaşma etkisi altında kalan su noktalarıdır. Y1 su noktası $-8.03 \delta^{18} 0$ (VSMOW \%o) içeriğine; DK su noktası ise $-0.86 \delta^{18} 0$ (VSMOW \%o) içeriğine sahiptir (Șekil 4).

Aralık 2019 dönemi duraylı izotop analiz sonuçlarına göre örneklerin ortalama Oksijen-18 $\left(\delta^{18} 0\right)$ ve Döteryum $\left(\delta^{2} \mathrm{H}\right)$ içerikleri ise sırasıyla -11.42 VSMOW (\%o) ve -82.64 VSMOW (\%o) olarak ölçülmüştür. Aralık ayı izotop örneklemesinin en düşük Oksijen-18 $\left(\delta^{18} 0\right)$ içeriği -20.32 VSMOW (\%o) ile alanın batısındaki Çimeli yerleşim yerinden örnekleme yapılan P3 kar noktası; en yüksek Oksijen-18 $\left(\delta^{18} 0\right)$ içeriği ise -3.29 VSMOW (\%o) değeri ile drenaj kanalını temsil eden DK su noktasıdır (Şekil 5).

En yüksek Döteryum $\left(\delta^{2} \mathrm{H}\right)$ içeriği -42.89 VSMOW ile (\%o) DK su noktası; en düşük Döteryum $\left(\delta^{2} \mathrm{H}\right)$ içeriği ise - 
154.92 VSMOW (\%o) ile havzanın batısındaki Paleozoyik yaşlı mermer seviyelerin yer aldığı Çimeli yerleşim yerinden örnekleme yapılan P3 kar noktasıdır (Tablo 2).

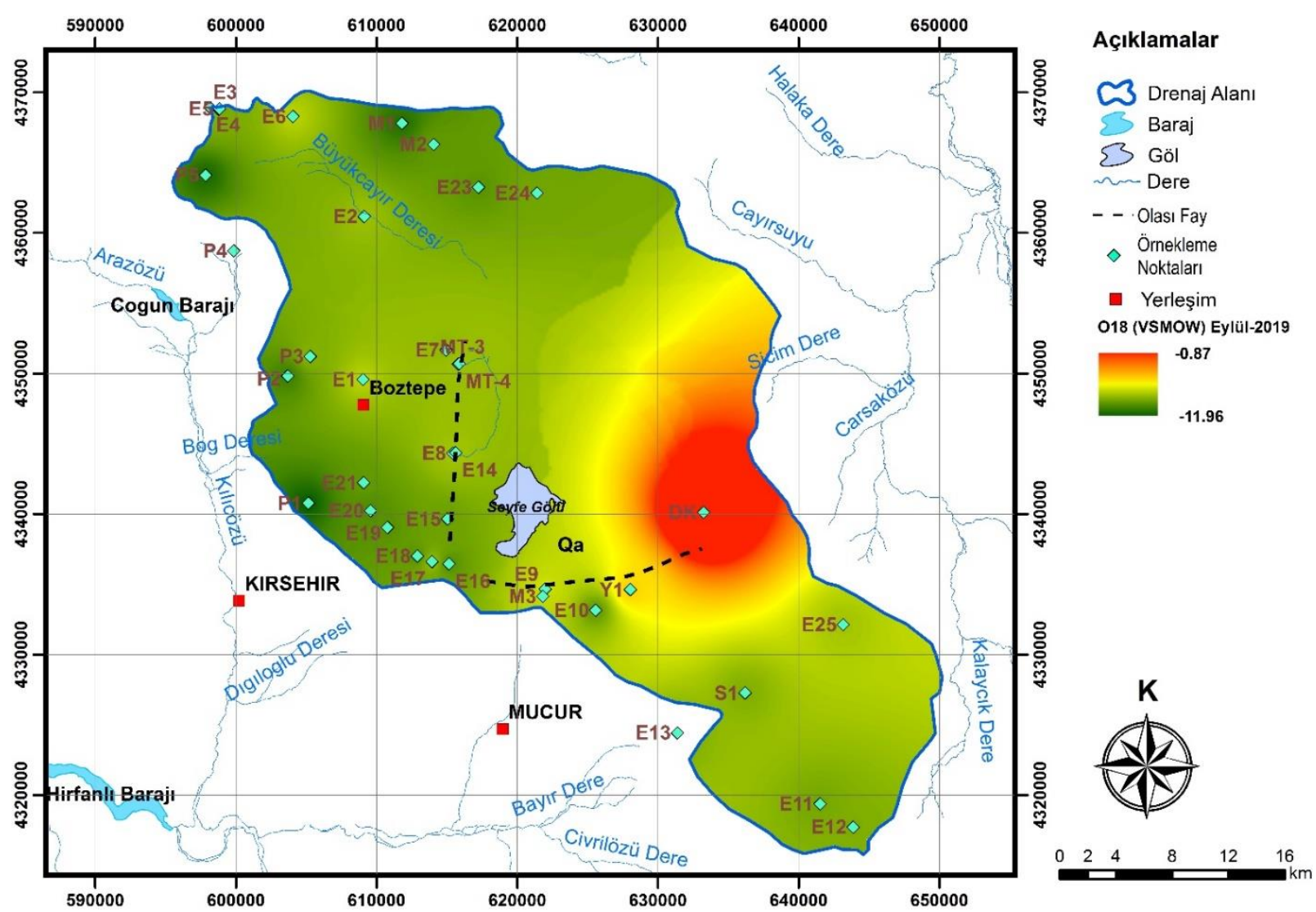

Şekil 4. Havzada örneklenen su noktalarının Oksijen-18 dağılımı, Eylül-2019) (Spatial distribution of Oxygen-18 values of the water samples in the basin, September-2019)

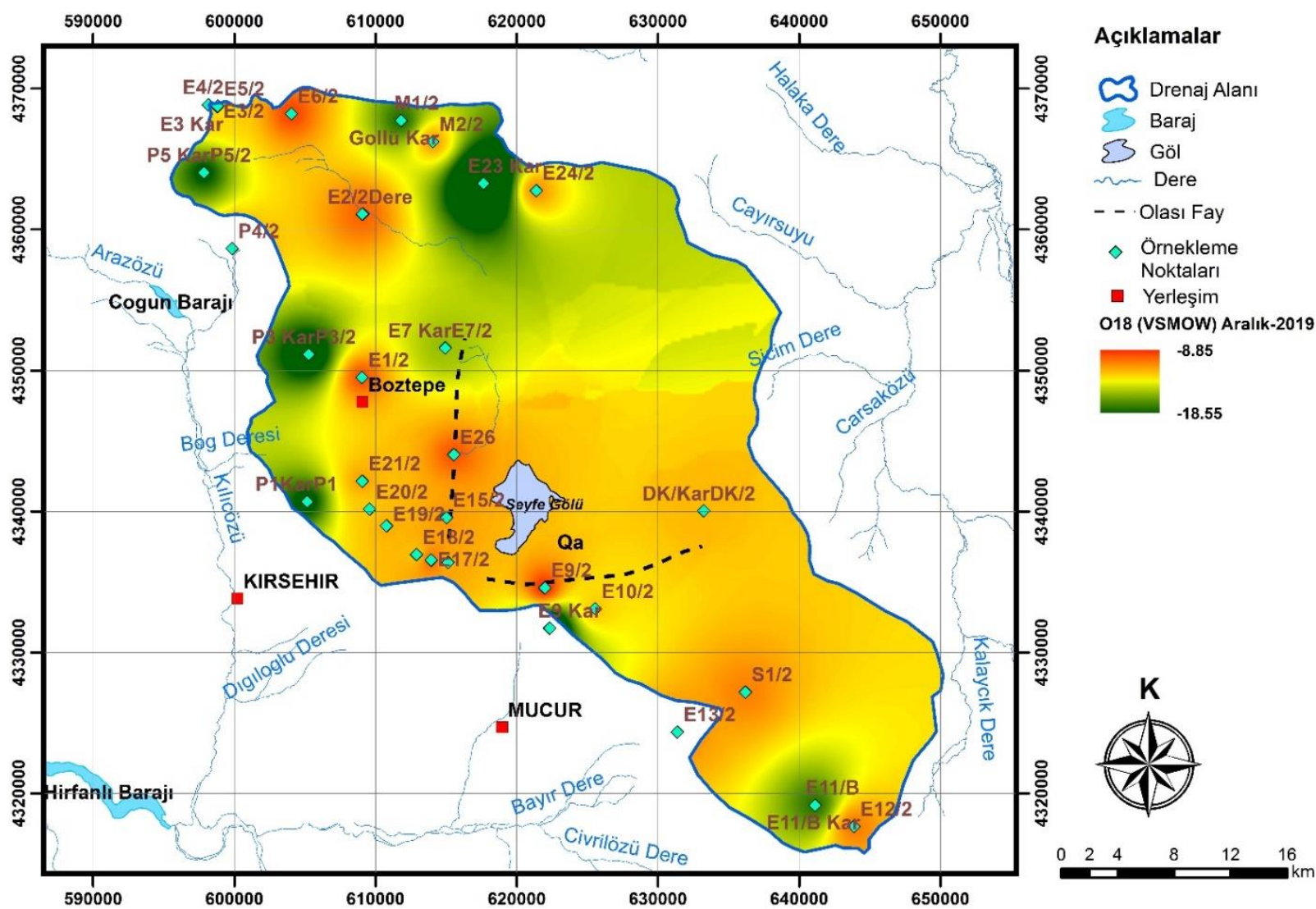

Sekil 5 Havzada örneklenen su noktalarının Oksijen-18 dağılımı, Aralık-2019) (Spatial distribution of Oxygen-18 values of the water samples in the basin, December-2019) 
Tablo 2. Çalışma alanında örneklenen su noktalarının duraylı izotop içerikleri-Aralık 2019 (Stable isotope contents of the water samples in the study area-December 2019)

\begin{tabular}{|c|c|c|c|}
\hline ARALIK 2019 & $\boldsymbol{\delta}^{\mathbf{2}}$ (PERMIL) & $\boldsymbol{\delta}^{\mathbf{1 8}} \mathbf{0}$ (PERMIL) & YÜKSELTI (M) \\
\hline Minumum & -154.92 & -20.32 & 1108 \\
\hline Maksimum & -42.89 & -3.29 & 1390 \\
\hline Ortalama & -82.64 & -11.42 & 1208 \\
\hline
\end{tabular}

\subsection{Oksijen 18-Döteryum İlişkisi (Relationship between Oxygen 18-Deuterium)}

İzotop hidrojeolojisi çalışmalarında meteorik suların duraylı izotop (Oksijen-18, Döteryum) içerikleri; enlem, sıcaklık, deniz seviyesinden yükseklik ve mevsimsel etkilere bağlı olarak değişmektedir (Gat ve Gonfiantini, 1981). Yağışa kaynak oluşturan su buharının duraylı izotop içeriği; sıcaklık düştükçe, düşük kotlardan yüksek kotlara çıkıldıkça ve düşük enlemlerden yüksek enlemlere doğru gittikçe negatifleşmektedir (Gat ve Gonfiantini, 1981). Yine mevsimsel olarak kış yağışları yaz yağışlarına göre daha fakir izotop içeriğine sahiptir (Clark ve Fritz, 1997).

Çalışma alanında örneklenen su noktalarının birbirlerinden oldukça farklı izotop içeriklerine sahip oldukları belirlenmiştir. Havzada örneklenen su noktalarının $\delta^{18} 0$ değerleri incelendiğinde; genellikle yükseklik arttıkça, izotop içeriklerinin negatifleștiği görülmektedir.

Örnekleme noktalarının çalışma alanı içerisindeki konumları, Eylül 2019 ve Aralık 2019 dönemlerinde yerinde ölçüm ve duraylı izotop analiz sonuçları sırasıyla Şekil 3, Şekil 4, Şekil 5, Tablo 3, Tablo 4, Tablo 5 ve Tablo 6'da verilmiştir. Havza ölçeğinde izotop örneklemesi yapılan su noktalarının Eylül 2019 ve Aralık 2019 dönemlerindeki Oksijen-18 ve Döteryum içerikleri şekiller üzerinde her iki dönem için gösterilmiştir (Şekil 6 ve Şekil 7).

Bu çalışmada yerel meteorik su doğrularını belirlemeye yönelik şekilde (kar örneklemeleri haricinde) dönemsel yağış örneklerinin izotop analizleri gerçekleștirilememiştir. Havzadaki arazi çalışmalarının devam etmesi nedeniyle yağış örneklemeleri yapıldıkça yağışların duraylı izotop analizleri gerçekleștirilecektir.

2019 Eylül ve 2019 Aralık dönemlerinin analiz sonuçları değerlendirildiğinde; örneklenen su noktalarının farklı meteorik doğrular üzerinde kümelendikleri görülmektedir. Havzada örneklenen su noktalarının; Küresel Meteorik Su Doğrusu dışında; yaklaşık olarak döteryum fazlası +15 ve +5 olan iki farklı meteorik doğru üzerinde yer aldıkları görülmektedir (Şekil 6 ve Şekil 7).

Eylül 2019 döneminde örneklenen E14, MT-3, MT-1, P4, E7, S1, E12, E13, E5, E11, E15, E10 ve E23 su noktaları ise döteryum fazlası +10 olan Küresel Meteorik Su Doğrusu (KMSD) üzerinde yer almaktadır. Küresel Meteorik Su Doğrusu dünyadaki çeşitli yağış istasyonlarından elde edilen yağışların duraylı izotop içeriklerine göre belirlenmiştir (Craig, 1961). Bu verilere göre global ölçekte, eğimi 8 döteryum fazlası +10 olan lineer bir ilişki ile temsil edilen su doğrusu belirlenmiștir (Craig, 1961). Bu örneklerden yeraltısuyunu temsil eden su noktaları Yenidoğanlı bölgesindeki MT-1 ve MT-3 kuyuları ile Seyfe köyündeki E15 kuyusudur. Havzadaki eğimi 8 olan doğru üzerinde kümelenen bu su noktaları meteorik kökenli yağışlardan beslenmektedir. Ayrıca çalışma alanında Üst Miyosen-Pliyosen yaşlı birimlerden çıkış yapan su noktalarının çoğunluğunun Küresel Meteorik Su Doğrusu üzerinde yer aldıkları görülmektedir.

DK ve Y1 su noktaları ise açık yüzeyden sürekli buharlaşma etkisi altında kalan su kütleleri olmaları nedeniyle Küresel Meteorik Su Doğrusundan sapma gösterip, eğimi yaklaş̧k olarak 5 olan buharlaşma eğrisi üzerinde yer almaktadır. Genellikle buharlașma doğrusunun eğimi 4 ile 6 arasında değişmektedir (Clark ve Fritz, 1997). Buharlaşma doğrusunun eğimini buharlaşmanın oluştuğu andaki bağıl nem düzeyi, sıcaklık gibi faktörler belirlemekle birlikte, bağıl nem miktarı arttıkça doğrunun eğimi artmaktadır (Clark ve Fritz, 1997). Bağıl nem içeriğinin \%25'den az olması durumunda buharlaşma doğrusunun eğimi 4'e yakın, bağıl nem içeriğinin \%25 ile \%75 arasında değişmesi durumunda ise doğrunun eğiminin 4 ile 5 arasında değişebileceği belirtilmektedir (Clark ve Fritz, 1997). Kırşehir Meteoroloji İstasyonu verilerine göre 1970’ten günümüze kadar ölçülmüș bağll nem miktarı \%60'tır. Dolayısıyla çalışma alanındaki DK ve Y1 örneklerinin üzerinde bulundukları buharlaşma doğrusunun eğimi ile havza yakınlarında ölçülen bağıl nem içeriği uyumlu bir ilişki göstermektedir.

Havzada her iki dönemde de bazı su noktaları ise döteryum fazlası +5 olan meteorik doğru üzerinde yer almaktadır. Döteryum fazlası değerindeki azalmanın nedenini inceleyen çalışmalar değerlendirildiğinde; kurakyarı kurak iklim bölgelerinde bu duruma yol açan etkinin "bulut altı buharlaşması" olabileceği belirtilmektedir. Bulut altı buharlaşma etkisi; bulut tabanının altından düșen yağışın havada tekrar tekrar buharlaşmaya uğraması ve izotopik farklılaşması ile açıklanmaktadır. Bu sürecin yağışın ağır izotoplarca zenginleşmesine neden olduğu ve 
düşük döteryum fazlası değerler göstermesi ile sonuçlandığı belirtilmektedir. (Froehlich vd., 2002; Gat, 2005; Peng vd., 2007; Delattre vd., 2015; Salamalikis vd., 2016; Bershaw, 2018).

Dolayısıyla Seyfe Gölü havzasındaki bazı su noktalarının düşük döteryum fazlası değerleri; gerek havzanın kurak iklim koşullarında olması; gerekse yağışın düşerken havada tekrar tekrar buharlaşmaya uğraması ve ağır izotoplarca zenginleșmesi gibi süreçlerin etkisi altında olabileceğini düşündürmektedir. Bununla birlikte döteryum fazlalığındaki değişime neden olan süreçlerin kapsamlı olarak açıklanabilmesi için; havza için temsil edici yağış örneklemelerinin gerçekleştirilmesi ve yorumların analizlerle desteklenmesi gerekmektedir.

Her iki dönemde de havzada metamorfik birimleri temsil eden su noktaları (E8, E17, P3, E21, M2, E19, E18, E16, E20, P2, M1, P1, P5) döteryum fazlası 15 olan doğru üzerinde yer almaktadır. Döteryum fazlası değerler havzada örneklenen su noktaları için Df $=\delta^{2} \mathrm{H}-8^{*} \delta^{18} \mathrm{O}$ eşitliğinden (Dansgaard, 1964) hesaplanmıştır. Döteryum fazlası değerler yağışı oluşturan buharlaşmanın kökenine işaret etmektedir (Gat vd., 1994). Ayrıca bu değerleri buharlaşma yüzeyinin sıcaklı̆̆ı, rüzgar hızı ve nem içeriği miktarı gibi faktörler kontrol etmektedir (Froehlich vd., 2002). Döteryum fazlası yüksek değerler denizel kökenli yağışları gösterirken, döteryum fazlası düşük değerler karasal kökenli yağıșları göstermektedir (Clark ve Fritz, 1997). Aynı yağış rejiminden etkilenen suların döteryum fazlası değerleri birbirlerine yakın değerler göstermektedir (Froehlich vd., 2002). Buna göre havzadaki su kaynaklarının farklı hatlar üzerinde kümelenmeleri nedeniyle alanda farklı kökenli yağıș rejimlerinin hakim olabileceği düșünülmektedir. Dolayısıyla aynı meteorik su doğrusu üzerinde bulunan su noktalarının benzer kökenli yağışlardan beslendikleri, farklı hatlara düşen su kaynaklarının ise farklı yağış rejimleriyle temsil edildikleri düşünülmektedir. Eylül-2019 ve Aralık-2019 analiz sonuçları değerlendirildiğinde havza batısını temsil eden meteorik doğrunun $\delta^{2} \mathrm{H}=8^{*} \delta^{18} 0+15$ şeklinde yazılabileceği düşünülmektedir. Ayrıca diğer örnekleme noktalarına göre daha yüksek döteryum fazlasına sahip olunması, havza batı-kuzeybatısının; doğusuna göre daha farklı bir topografya, iklim koşulları veya farklı bir yağış rejimi ile temsil edildiğini düşündürmektedir. Bu durum havza batısının denizel kökenli yağışların etkisinde olduğu, buharlaşmanın hızlı ve ortamdaki nem düzeyinin düşük olduğunu göstermektedir.

Çalışma alanındaki döteryum fazlası +15 ve +15 'e yakınsayan değerlere sahip su noktaları genellikle havzanın batı-kuzeybatısında yer almaktadır. Döteryum fazlası +15 olan doğru üzerinde yer alan P1, P5 ve M1 kaynakları ise havzanın en yüksek kotlarını temsil etmektedir. Bu kaynaklar diğer su noktalarına göre daha yüksek kotlarda yer almaktadır ve yükseltiye bağlı olarak $\delta^{18} 0$ içerikleri daha negatiftir (Şekil 6, Şekil 7). Dolayısıyla bu su noktalarının beslenim alanı yükseltileri diğer su noktalarına göre daha yüksektir. Ayrıca havzanın doğusundan batı-kuzeybatısına doğru akım yolu boyunca yükseltinin artmasıyla birlikte su noktalarının Oksijen-18 ve Döteryum içeriklerinin negatifleştiği görülmektedir (Şekil 8).

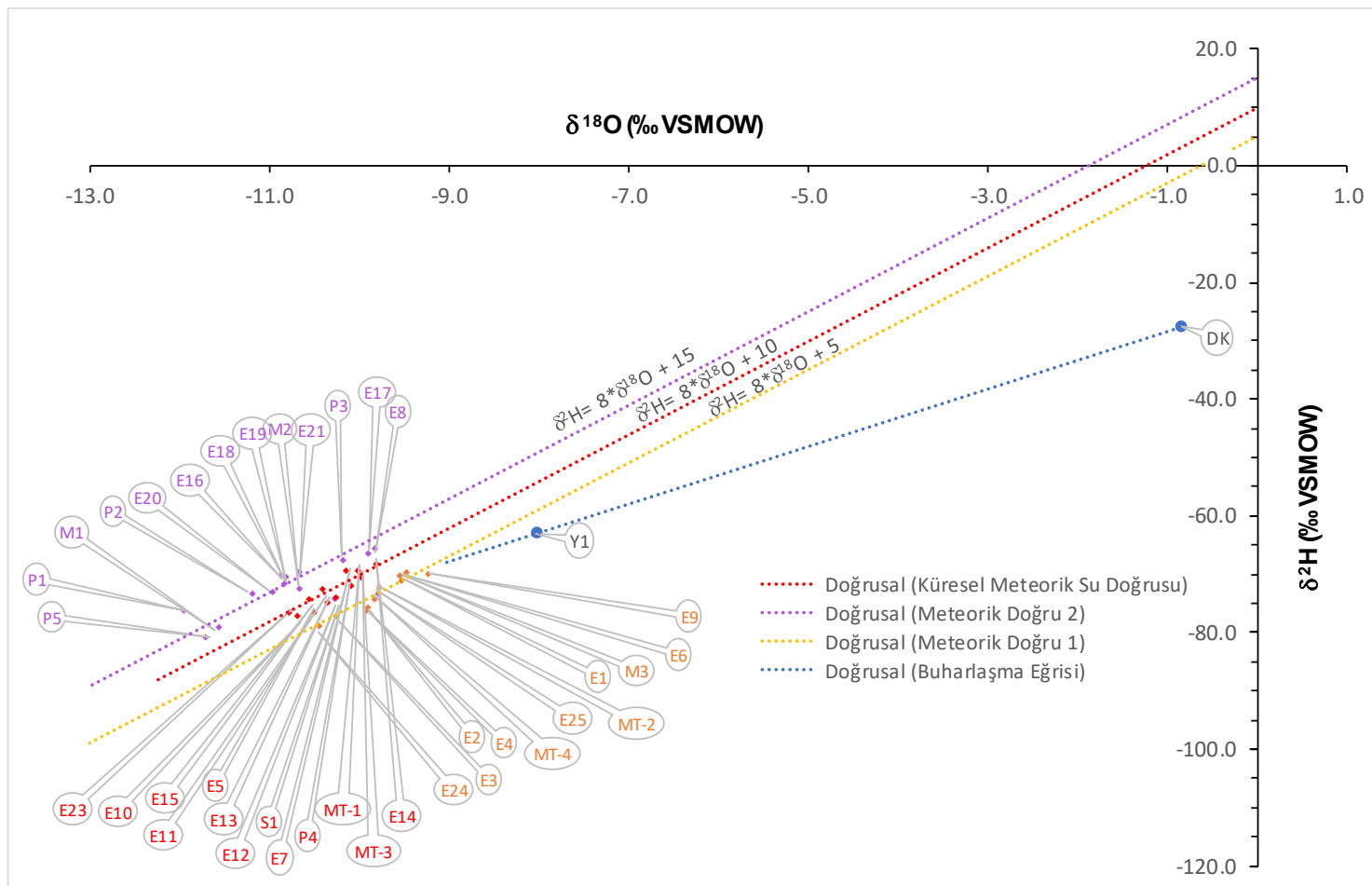

Şekil 6. Havzadaki su noktalarının $\delta^{180}$ ve $\delta^{2} \mathrm{H}$ grafiği, Eylül-2019 (Plot of stable isotope contents $\left(\delta^{18} \mathrm{O}\right.$ ve $\delta^{2} \mathrm{H}$ )of the water samples in the basin, September-2019) 


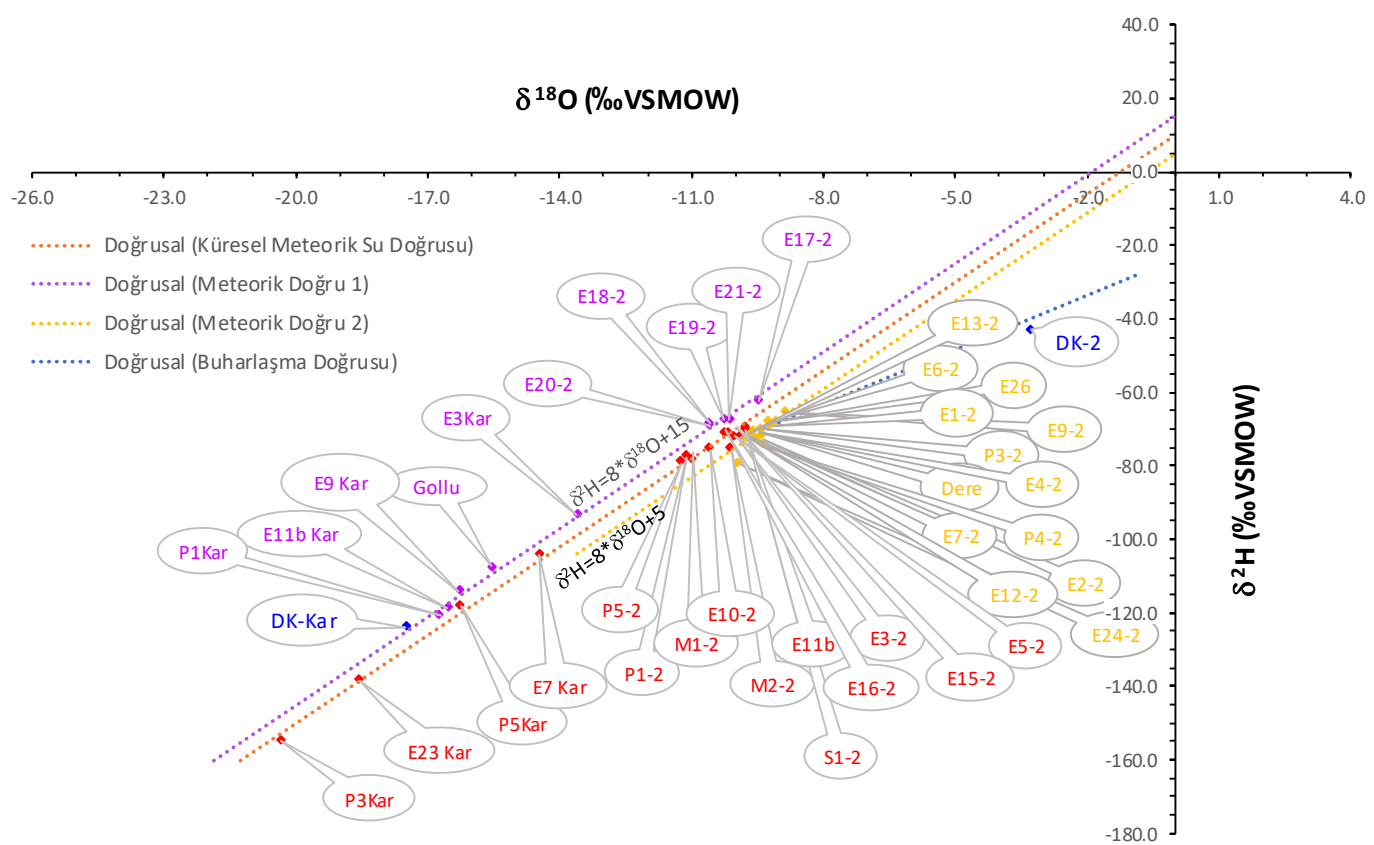

Şekil 7. Havzadaki su noktalarının $\delta^{18} \mathrm{O}$ ve $\delta^{2} \mathrm{H}$ grafiği, Aralık-2019 (Plot of stable isotope contents $\left(\delta^{18} \mathrm{O}\right.$ ve $\left.\delta^{2} \mathrm{H}\right)$ of the water samples in the basin, December-2019)
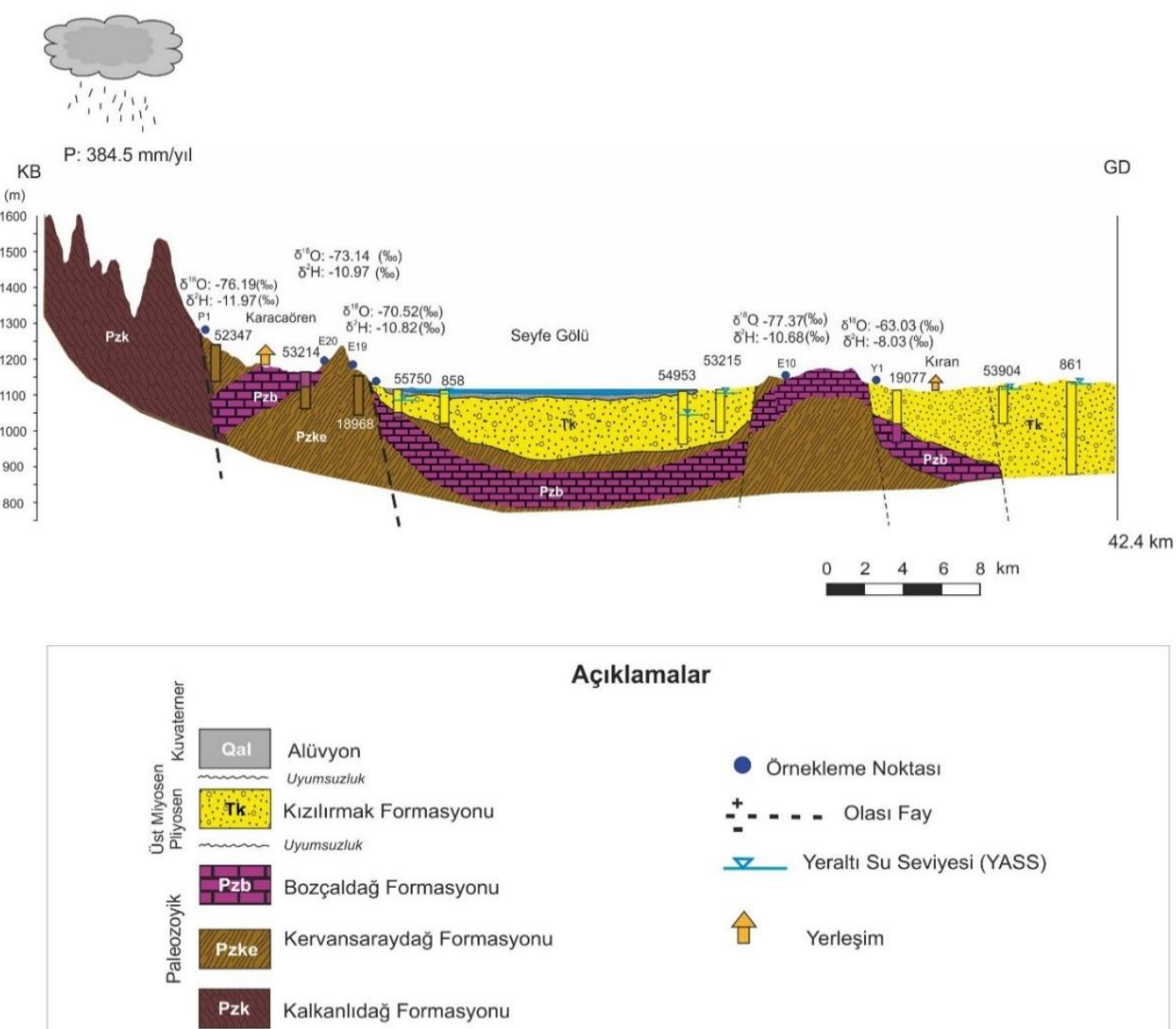

Açıklamalar

Örnekleme Noktası

_. - - - Olası Fay

$\nabla \quad$ Yeraltı Su Seviyesi (YASS)

प Yerleşim

Şekil 8. Havzanın KB-GD hattında șematik izotopik değișim (Schematic representation of the change in stable isotope contents from NW to SE of the basin) 
Tablo 3. Seyfe Gölü havzasındaki örnekleme noktalarının yerinde ölçümleri, Eylül 2019 (Insitu measurements of the water samples in the Seyfe Lake basin, September 2019)

\begin{tabular}{|c|c|c|c|c|c|c|}
\hline ÖRNEK NO & $\mathbf{X}$ & $\mathbf{Y}$ & YÜKSELTİ (m) & $\mathbf{T}$ & pH & ÖEIं $25(\mu S / \mathrm{cm})$ \\
\hline $\mathrm{P} 1$ & 605156 & 4340698 & 1370 & 15.7 & 8.02 & 410 \\
\hline $\mathrm{P} 2$ & 603666 & 4349747 & 1240 & 17.6 & 7.32 & 710 \\
\hline P3 & 605284 & 4351136 & 1220 & 15.8 & 7.84 & 370 \\
\hline $\mathrm{P} 4$ & 599847 & 4358648 & 1190 & 16.2 & 7.52 & 810 \\
\hline P5 & 597851 & 4364038 & 1328 & 15.9 & 7.39 & 550 \\
\hline E1 & 609035 & 4349498 & 1155 & 19.4 & 7.86 & 460 \\
\hline $\mathrm{E} 2$ & 609110 & 4361089 & 1144 & 18.2 & 7.51 & 910 \\
\hline E3 & 598788 & 4368698 & 1260 & 14.8 & 7.58 & 720 \\
\hline $\mathrm{E} 4$ & 598155 & 4368843 & 1230 & 18.3 & 7.65 & 630 \\
\hline E5 & 598819 & 4368745 & 1265 & 16.4 & 7.73 & 720 \\
\hline E6 & 604037 & 4368211 & 1228 & 19.9 & 7.65 & 680 \\
\hline M1 & 611807 & 4367723 & 1285 & 14.5 & 7.79 & 640 \\
\hline M2 & 614056 & 4366218 & 1215 & 15.3 & 7.55 & 760 \\
\hline E7 & 614936 & 4351591 & 1142 & 20.7 & 7.86 & 690 \\
\hline E8 & 615409 & 4344250 & 1120 & 20.3 & 7.74 & 640 \\
\hline E9 & 621977 & 4334584 & 1121 & 17.4 & 7.84 & 540 \\
\hline M3 & 621810 & 4334070 & 1127 & 16.3 & 7.78 & 550 \\
\hline E10 & 625560 & 4333087 & 1200 & 17.6 & 7.77 & 780 \\
\hline $\mathrm{Y} 1$ & 628030 & 4334549 & 1119 & 19.9 & 8.05 & 1330 \\
\hline $\mathrm{S} 1$ & 636184 & 4327195 & 1142 & 21.2 & 7.2 & 3400 \\
\hline E11 & 641503 & 4319309 & 1187 & 16.3 & 7.93 & 660 \\
\hline E12 & 643866 & 4317658 & 1228 & 14.5 & 7.73 & 690 \\
\hline E13 & 631372 & 4324354 & 1204 & 19.5 & 7.96 & 670 \\
\hline E14 & 615615 & 4344289 & 1118 & 20.5 & 7.8 & 640 \\
\hline E15 & 615029 & 4339571 & 1131 & 16.2 & 8.25 & 740 \\
\hline E16 & 615133 & 4336386 & 1188 & 18 & 7.78 & 750 \\
\hline E17 & 613930 & 4336540 & 1194 & 17.2 & 7.85 & 820 \\
\hline E18 & 612891 & 4336936 & 1238 & 17.6 & 7.48 & 870 \\
\hline E19 & 610775 & 4338976 & 1216 & 18.4 & 7.74 & 510 \\
\hline E20 & 609570 & 4340156 & 1215 & 17.8 & 7.71 & 540 \\
\hline E21 & 609065 & 4342152 & 1200 & 17.3 & 7.81 & 530 \\
\hline MT-1 & 615820 & 4350596 & 1133 & 15.9 & 7.62 & 1730 \\
\hline MT-2 & 615813 & 4350581 & 1114 & 16.1 & 7.54 & 2010 \\
\hline MT-3 & 615790 & 4350582 & 1120 & 16.3 & 7.54 & 2000 \\
\hline MT-4 & 615869 & 4350611 & 1116 & 15.8 & 7.52 & 2340 \\
\hline E23 & 617234 & 4363173 & 1163 & 17.5 & 7.85 & 690 \\
\hline E24 & 621376 & 4362765 & 1176 & 16.3 & 7.15 & 1460 \\
\hline E25 & 643158 & 4332052 & 1126 & 15.2 & 7.84 & 950 \\
\hline DK & 633231 & 4340043 & 1108 & 19.7 & 8.65 & 30500 \\
\hline
\end{tabular}


Tablo 4. Seyfe Gölü havzasındaki örneklenen su noktalarının duraylı izotop içerikleri, Eylül 2019 (Stable isotope contents of the water samples in Seyfe Lake basin, September 2019)

\begin{tabular}{|c|c|c|c|c|c|}
\hline ÖRNEK NO & $\begin{array}{c}\delta^{2} \mathrm{H} \\
\text { (\%oVSMOW) }\end{array}$ & $\begin{array}{c}\delta^{180} \\
(\% \circ V S M O W)\end{array}$ & $\begin{array}{c}\text { DÖTERYUM } \\
\text { FAZLASI (DF) }\end{array}$ & YÜKSELTİ (m) & YERLEŞİM \\
\hline P1 & -76.19 & -11.37 & 14.8 & 1370 & Boztepe yolu \\
\hline $\mathrm{P} 2$ & -73.39 & -11.2 & 16.2 & 1240 & Çimeli \\
\hline P3 & -67.54 & -10.19 & 14.0 & 1220 & Çimeli \\
\hline $\mathrm{P} 4$ & -72.23 & -10.09 & 8.5 & 1190 & Kırkpınar \\
\hline P5 & -80.88 & -11.72 & 12.9 & 1328 & Hamurlu Besler \\
\hline E1 & -71.13 & -9.53 & 5.1 & 1155 & Külhüyük \\
\hline E2 & -76.54 & -9.91 & 2.7 & 1144 & Harmanaltı \\
\hline E3 & -77.17 & -10.25 & 4.8 & 1260 & Yukarı Hamurlu \\
\hline E4 & -76 & -9.89 & 3.1 & 1230 & Yukarı Hamurlu \\
\hline E5 & -76.65 & -10.5 & 7.3 & 1265 & Yukarı Hamurlu \\
\hline E6 & -70.33 & -9.55 & 6.1 & 1228 & Kartalkaya \\
\hline M1 & -79.12 & -11.56 & 13.4 & 1285 & Göllü \\
\hline M2 & -72.53 & -10.67 & 12.8 & 1215 & Uzunpınar \\
\hline E7 & -69.67 & -10.13 & 11.4 & 1142 & Yenidoganlı \\
\hline E8 & -65.66 & -9.83 & 13.0 & 1120 & Eskidoğanlı \\
\hline E9 & -70.04 & -9.23 & 3.8 & 1121 & Yazıkınık \\
\hline M3 & -69.76 & -9.46 & 5.9 & 1127 & Yazıkınık \\
\hline E10 & -77.37 & -10.68 & 8.1 & 1200 & Budak \\
\hline $\mathrm{Y} 1$ & -63.03 & -8.03 & 1.2 & 1119 & Geyicek \\
\hline S1 & -74.24 & -10.25 & 7.8 & 1142 & Büyükburunağıl \\
\hline E11 & -72.63 & -10.39 & 10.5 & 1187 & İlicek \\
\hline E12 & -74.19 & -10.28 & 8.1 & 1228 & Avuç \\
\hline E13 & -74.95 & -10.35 & 7.8 & 1204 & Obruk \\
\hline E14 & -68.47 & -9.81 & 10.0 & 1118 & Eskidoğanlı \\
\hline E15 & -74.35 & -10.54 & 10.0 & 1131 & Seyfe \\
\hline E16 & -70.24 & -10.88 & 16.8 & 1188 & Gümüşkümbet \\
\hline E17 & -66.45 & -9.9 & 12.8 & 1194 & Dalakçı \\
\hline E18 & -71.75 & -10.83 & 14.9 & 1238 & Dalakçı \\
\hline E19 & -70.52 & -10.82 & 16.0 & 1216 & Karacaören \\
\hline E20 & -73.14 & -10.97 & 14.6 & 1215 & Karacaören \\
\hline E21 & -69.69 & -10.66 & 15.6 & 1200 & Karacaören \\
\hline MT-1 & -69.57 & -10 & 10.4 & 1133 & Yenidoğanlı \\
\hline MT-2 & -72.5 & -9.77 & 5.7 & 1114 & Yenidoğanlı \\
\hline MT-3 & -70.72 & -9.97 & 9.0 & 1120 & Yenidoğanlı \\
\hline MT-4 & -74.33 & -9.82 & 4.2 & 1116 & Yenidoğanlı \\
\hline E23 & -76.79 & -10.77 & 9.4 & 1163 & H.Öksüzkale \\
\hline E24 & -79.14 & -10.43 & 4.3 & 1176 & Üçkuyu Köyü \\
\hline E25 & -73.35 & -9.79 & 5.0 & 1126 & Hasanlar \\
\hline DK & -27.61 & -0.86 & -20.73 & 1108 & Drenaj Kanalı \\
\hline Minumum & -80.88 & -11.97 & -20.7 & 1108 & \\
\hline Maksimum & -27.61 & -0.86 & 16.8 & 1370 & \\
\hline Ort.Hata Payı & 0.41 & 0.07 & & & \\
\hline
\end{tabular}


Tablo 5. Seyfe Gölü havzasındaki su noktalarının yerinde ölçüm değerleri, Aralık 2019 (Insitu measurements of the water samples in the Seyfe Lake basin, December 2019)

\begin{tabular}{|c|c|c|c|c|c|c|}
\hline ÖRNEK NO & $\mathbf{X}$ & $\mathbf{Y}$ & YÜKSELTİ (m) & $\mathbf{T}$ & pH & ÖEİ $25^{\circ}(\mu S / \mathrm{cm})$ \\
\hline $\mathrm{P} 1 / 2$ & 605156 & 4340698 & 1370 & 9.1 & 7.65 & 291 \\
\hline P1 Kar & 605156 & 4340698 & 1390 & - & $* 6.86$ & $* 62$ \\
\hline P3/2 & 605284 & 4351136 & 1220 & 10.06 & 7.43 & 405 \\
\hline P3 Kar & 605284 & 4351136 & 1220 & - & $* 7.11$ & $* 52$ \\
\hline $\mathrm{P} 4 / 2$ & 599847 & 4358648 & 1190 & 12.97 & 7.56 & 598 \\
\hline P5/2 & 597851 & 4364038 & 1328 & 11.95 & 7.25 & 406 \\
\hline P5 Kar & 597851 & 4364038 & 1328 & - & $* 7.18$ & $* 47$ \\
\hline E1/2 & 609035 & 4349498 & 1155 & 4.05 & 6.38 & 412 \\
\hline $\mathrm{E} 2 / 2$ & 609110 & 4361089 & 1144 & 8.62 & 7.44 & 642 \\
\hline Dere & 609058 & 4361074 & 1145 & 2.01 & 8.39 & 825 \\
\hline E3/2 & 598788 & 4368698 & 1260 & 12.37 & 7.65 & 515 \\
\hline E3 Kar & 598788 & 4368698 & 1260 & - & $* 7.34$ & $* 32$ \\
\hline $\mathrm{E} 4 / 2$ & 598155 & 4368843 & 1230 & 8.73 & 7.43 & 446 \\
\hline E5/2 & 598819 & 4368745 & 1265 & 10.96 & 7.50 & 531 \\
\hline E6/2 & 604037 & 4368211 & 1228 & 12.37 & 7.65 & 515 \\
\hline M1/2 & 611807 & 4367723 & 1285 & 12.05 & 7.65 & 580 \\
\hline Göllü Kar & 611807 & 4367723 & 1285 & - & $* 7.06$ & $* 38$ \\
\hline $\mathrm{M} 2 / 2$ & 614056 & 4366218 & 1215 & 12.21 & 7.47 & 538 \\
\hline $\mathrm{E} 7 / 2$ & 614936 & 4351591 & 1142 & 5.86 & 7.60 & 1029 \\
\hline E7 Kar & 614931 & 4351599 & 1142 & - & $* 6.83$ & $* 182$ \\
\hline $\mathrm{E} 9 / 2$ & 621977 & 4334584 & 1121 & 10.57 & 7.56 & 396 \\
\hline E9 Kar & 622321 & 4331721 & 1168 & - & $* 7.17$ & $* 40$ \\
\hline $\mathrm{E} 10 / 2$ & 625560 & 4333087 & 1200 & 6.27 & 7.67 & 514 \\
\hline $\mathrm{S} 1 / 2$ & 636184 & 4327195 & 1142 & 4.3 & 7.20 & 2733 \\
\hline E11/B Kar & 641133 & 4319169 & 1188 & - & $* 7.25$ & $* 47$ \\
\hline E11/B & 641133 & 4319169 & 1188 & 8.71 & 7.35 & 634 \\
\hline E12/2 & 643866 & 4317658 & 1228 & 11.38 & 7.57 & 503 \\
\hline E13/2 & 631372 & 4324354 & 1204 & 8.74 & 7.79 & 498 \\
\hline E15/2 & 615029 & 4339571 & 1131 & 15.02 & 7.87 & 541 \\
\hline $\mathrm{E} 16 / 2$ & 615133 & 4336386 & 1188 & 6.45 & 8.27 & 527 \\
\hline $\mathrm{E} 17 / 2$ & 613930 & 4336540 & 1194 & 6.03 & 7.67 & 587 \\
\hline E18/2 & 612891 & 4336936 & 1238 & 6.66 & 7.28 & 644 \\
\hline E19/2 & 610775 & 4338976 & 1216 & 6.46 & 7.63 & 356 \\
\hline E20/2 & 609570 & 4340156 & 1215 & 6.58 & 7.22 & 402 \\
\hline E21/2 & 609065 & 4342152 & 1200 & 9.53 & 7.32 & 390 \\
\hline E23 Kar & 617638 & 4363257 & 1183 & - & $* 6.94$ & $* 45$ \\
\hline $\mathrm{E} 24 / 2$ & 621376 & 4362765 & 1176 & 13.66 & 7.09 & 1050 \\
\hline E26 & 615533 & 4344035 & 1120 & 8.66 & 7.57 & 452 \\
\hline $\mathrm{DK} / 2$ & 633231 & 4340043 & 1108 & 4.13 & 8.61 & 29850 \\
\hline DK/Kar & 633231 & 4340043 & 1108 & - & $* 8.02$ & $* 65$ \\
\hline
\end{tabular}

(*Labda ölçülmüştür.) 
Tablo 6. Seyfe Gölü havzasında örneklenen su noktalarının duraylı izotop içerikleri, Aralık 2019 (Stable isotope contents of the water samples in Seyfe Lake basin, December2019)

\begin{tabular}{|c|c|c|c|c|c|}
\hline ÖRNEK NO & $\begin{array}{c}\delta^{2} \mathrm{H} \\
(\% \circ V S M O W)\end{array}$ & $\begin{array}{c}\delta^{180} \\
(\% \circ V S M O W)\end{array}$ & $\begin{array}{c}\text { DÖTERYUM } \\
\text { FAZLASI (DF) }\end{array}$ & YÜKSELTİ (m) & YERLEŞİM \\
\hline $\mathrm{P} 1 / 2$ & -77.42 & -11.1 & 11.4 & 1370 & Boztepe \\
\hline P1 Kar & -120.7 & -16.72 & 13.1 & 1390 & Boztepe \\
\hline P3/2 & -70.12 & -9.44 & 5.4 & 1220 & Çimeli \\
\hline P3Kar & -154.92 & -20.32 & 7.6 & 1220 & Çimeli Kar \\
\hline $\mathrm{P} 4 / 2$ & -74.25 & -9.4 & 1.0 & 1190 & Kırkpınar \\
\hline $\mathrm{P} 5 / 2$ & -79.01 & -11.26 & 11.1 & 1328 & Hamurlu Besler \\
\hline P5 Kar & -118 & -16.26 & 12.1 & 1328 & Hamurlu Besler \\
\hline $\mathrm{E} 1 / 2$ & -69.03 & -9.23 & 4.8 & 1155 & Külhüyük \\
\hline $\mathrm{E} 2 / 2$ & -72.75 & -9.5 & 3.3 & 1144 & Harmanaltı \\
\hline Dere & -71.56 & -9.38 & 3.5 & 1145 & Kepir Dere \\
\hline E3/2 & -72.27 & -9.89 & 6.9 & 1260 & Yukarı Hamurlu \\
\hline E3Kar & -93.27 & -13.59 & 15.5 & 1260 & Yukarı Hamurlu \\
\hline $\mathrm{E} 4 / 2$ & -70.56 & -9.59 & 6.2 & 1230 & Yukarı Hamurlu \\
\hline $\mathrm{E} 5 / 2$ & -71.19 & -10.15 & 10.0 & 1265 & Yukarı Hamurlu \\
\hline E6/2 & -67.78 & -9.1 & 5.0 & 1228 & Kartalkaya \\
\hline M1/2 & -78.05 & -10.98 & 9.8 & 1285 & Göllü \\
\hline Göllü Kar & -107.9 & -15.55 & 16.5 & 1285 & Göllü Kar \\
\hline M2/2 & -75.07 & -10.11 & 5.8 & 1215 & Uzunpınar \\
\hline $\mathrm{E} 7 / 2$ & -71.88 & -9.62 & 5.1 & 1142 & Yenidoğanlı \\
\hline E7 Kar & -103.97 & -14.46 & 11.7 & 1142 & Yenidoğanlı Kar \\
\hline $\mathrm{E} 9 / 2$ & -65.33 & -8.85 & 5.5 & 1121 & Yazıkınık \\
\hline E9 Kar & -113.83 & -16.28 & 16.4 & 1168 & Yazıkınık Kar \\
\hline E10/2 & -75.15 & -10.58 & 9.5 & 1200 & Budak \\
\hline $\mathrm{S} 1 / 2$ & -69.51 & -9.78 & 8.7 & 1142 & Büyükburunağıl \\
\hline E11b Kar & -118.62 & -16.53 & 13.6 & 1188 & İlicek \\
\hline E11b & -70.09 & -9.79 & 8.2 & 1188 & İlicek/b \\
\hline $\mathrm{E} 12 / 2$ & -71.52 & -9.68 & 5.9 & 1228 & Avuç \\
\hline $\mathrm{E} 13 / 2$ & -72.74 & -9.83 & 5.9 & 1204 & Obruk \\
\hline $\mathrm{E} 15 / 2$ & -71.83 & -10.03 & 8.4 & 1131 & Seyfe \\
\hline E16/2 & -70.77 & -10.26 & 11.3 & 1188 & Gümüşkümbet \\
\hline E17/2 & -62.03 & -9.47 & 13.7 & 1194 & Dalakçı \\
\hline E18/2 & -68.3 & -10.59 & 16.4 & 1238 & Dalakçı \\
\hline E19/2 & -67.25 & -10.27 & 14.9 & 1216 & Karacaören \\
\hline $\mathrm{E} 20 / 2$ & -68.97 & -10.59 & 15.8 & 1215 & Karacaören \\
\hline $\mathrm{E} 21 / 2$ & -67.55 & -10.14 & 13.6 & 1200 & Karacaören \\
\hline E23 Kar & -138.45 & -18.56 & 10.0 & 1183 & Hatunoğlu \\
\hline E24/2 & -79.16 & -9.96 & 0.5 & 1176 & Üçkuyu Köyü \\
\hline E26 & -68.15 & -9.28 & 6.1 & 1120 & Eskidoğanlı \\
\hline $\mathrm{DK} / 2$ & -42.89 & -3.29 & -16.6 & 1108 & Drenaj kanalı \\
\hline DK/Kar & -123.98 & -17.47 & 15.78 & 1108 & Drenaj kanalı \\
\hline Minumum & -154.92 & -20.32 & -16.57 & 1108 & \\
\hline Maksimum & -42.89 & -3.29 & 16.50 & 1390 & \\
\hline Ort. Hata Payı & 0.59 & 0.08 & & & \\
\hline
\end{tabular}

\subsection{Oksijen-18 Beslenim Alanı Yükseltisi İlişkisi (Relationship Between Oxygen18 and Recharge Elevation)}

İzotop hidrolojisi çalışmalarında havza ölçeğinde çeşitli su noktalarından gerçekleştirilen örneklemelerde kaynakların, yeraltısularının hangi yükseltilerden beslendiği ve yükselti ile duraylı izotop içeriklerinin nasıl değiştiğinin belirlenmesi oldukça önemlidir. Bu süreçlerin belirlenmesinde Oksijen-18 duraylı izotopundan yararlanılmaktadır.

Yağıştan itibaren beslenim gerçekleştikten sonra, suyun akifer içerisindeki hareketi sırasında sıcaklıkta belirgin bir değişim olmadığı sürece duraylı Oksijen-18 izotopu içeriğinde bir farklılaşma görülmediği belirtilmektedir (Dansgaard, 1964). Dolayısıyla bu durumda boşalım noktasında örneklenen suyun duraylı oksijen izotopu içeriği beslenim koşullarındaki izotop içeriğini yansıtıcaktır. Bu nedenle bu çalışma kapsamında örneklenen su noktalarının beslenim alanı yükseltisi hesaplamalarında Oksijen-18 izotopu kullanılmıştır.

Bu çalışma kapsamında yağıș verilerinin yetersiz olması nedeniyle Oksijen-18'in yükselti ile değișim oranı, 
mevsimsel örneklenen kaynak çıkışları dikkate alınarak belirlenmiştir.

Genellikle yapılan çalışmalarda her 100 m'lik yükselti artışına, Oksijen-18 içeriğindeki fakirleşme miktarı \%o 0.15 ile \%o 0.50 arasında değişmektedir. Döteryum içeriğindeki fakirleşme ise \%o1.0 ile \%o 4.0 arasındadır (Clark ve Fritz, 1997).

Havzadaki örneklerin gruplandırılması için eğimi 8 olan Küresel Meteorik Su Doğrusu temel alınmıştır. Buna göre farklı meteorik doğrular üzerinde kümelenmeler olduğu görülmüştür. Bu nedenle örneklerin beslenim alanı hesaplamalarında çeşitli gruplar belirlenmiştir. 1. grup için havzanın batısında +15 döteryum fazlası doğru üzerinde kümelenen, düşük debili akış yapan, metamorfik birimlerden çıkış yapan ve düşük elektriksel iletkenlik değerine sahip (P1, P2, P5, E8, E18, E19, E20 ve E21) su noktaları seçilmiştir (Şekil 9). Bu su noktaları ile yükseltiye karşılık Oksijen-18 ve Döteryum değişimini ifade eden regresyon eşitlikleri türetilmiştir. Havza genelinde Oksijen18 izotopu ile türetilen regresyon eşitlikleri kaynak çıkış kotu ile beslenim alanı yükseltisi açısından daha anlamlı bir ilişki sunmuştur.

Havzanın batısı için Oksijen-18 ve Döteryum yükseklik ilişkilerine göre türetilen regresyon eşitlikleri aşağıda verilmiştir (Eşitlik 1 ve Eşitlik 2).

$$
\begin{aligned}
& \delta^{18} \mathrm{O}=-0.0083 * \text { Yükseklik }(\mathrm{h})-0.6748\left(\mathrm{R}^{2}=0.96\right) \\
& \delta^{2} \mathrm{H}=-0.0522 * \text { Yükseklik }(\mathrm{h})-7.9125\left(\mathrm{R}^{2}=0.79\right)
\end{aligned}
$$

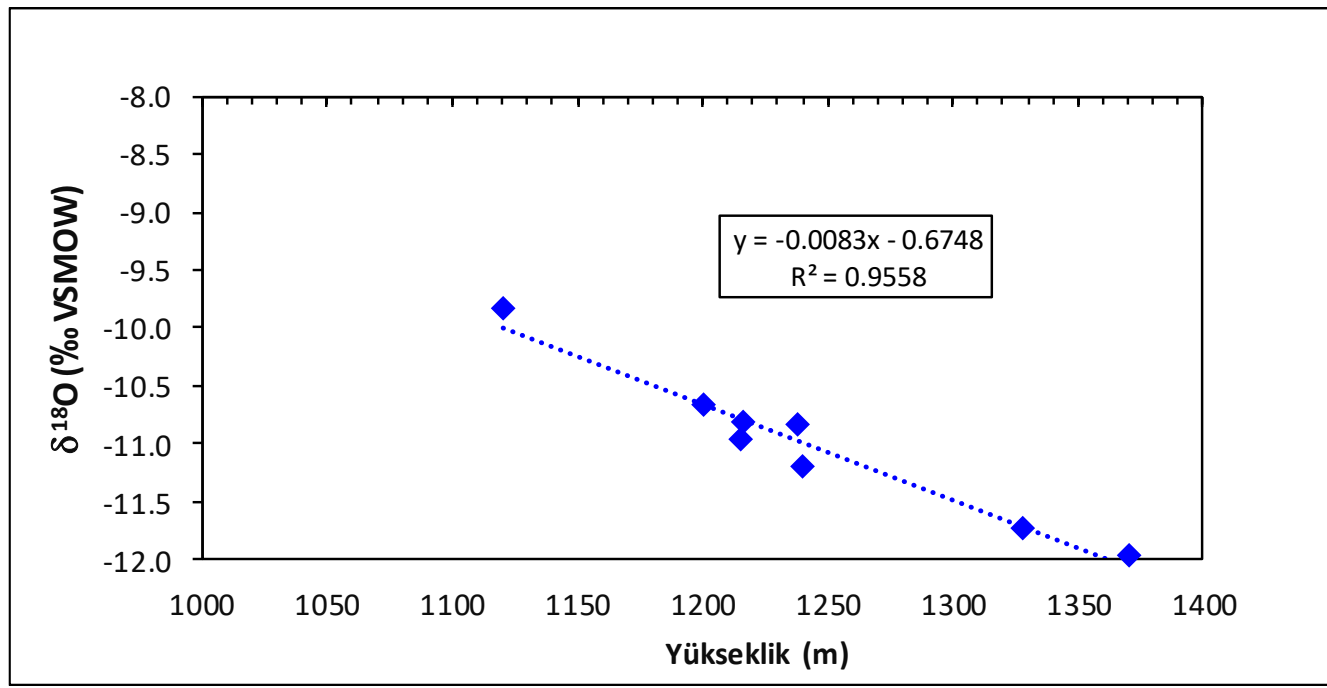

Şekil 9. Havzanın batısı için yükseklik-Oksijen-18 ilişkisi (Relationship between elevation and Oxygen18 for the western part of the basin)

Buna göre havzanın batısını temsil eden regresyon eşitliğine göre her 100 m' lik yükseklik artışına bağlı olarak ${ }^{18} 0$ içeriğindeki azalmanın \%o 0.8; ${ }^{2} \mathrm{H}$ içeriğindeki azalmanın ise \%o 5.2 oranında olduğu hesaplanmıştır. Havzanın batısında yer alan su kaynakları için türetilen Oksijen 18- yükseklik ilişkili regresyon eşitlikleri ile hesaplanan beslenim alanı yükselti hesaplamalarına göre; kaynakların, havzanın batı-güneybatı hattını sınırlayan Kervansaray Dağları'nın 1200 m ile 1350 m arasında değișen yükseltilerinden beslenebilecekleri belirlenmiştir.

Çalışma alanı içerisinde Yenidoğanlı-Eskidoğanlı-Seyfe-Gümüşkümbet-Budak köylerinden geçen K-G uzanımlı olası gömülü fay hattının bulunduğu ve Seyfe Gölü havzasını besleyen ana kaynakların (Seyfe, Horla, Yenidoğanlı) fay hattı boyunca sıralandıkları literatürdeki çalışmalarda (DSİ, 1979; DSİ, 2004; MTA, 2009) belirtilmiștir. Bu kapsamda gerçekleştirilen arazi çalışmalarında 2. grup olarak K-G hattını temsil ettiği düşünülen E7, E10, E14, MT 1, MT-2, MT-3 ve MT-4 su noktaları seçilmiş ve örneklenmiştir. Bu su noktaları kuzey güney hattı boyunca yüzeylemişlerdir. Havzanın kuzey-güney bölümü için seçilen su noktaları ile türetilen Oksijen-18 yükseklik değişimini ifade eden regresyon eșitliği aşağıda verilmiştir (Eşitlik 3).

$$
\delta^{18} \mathrm{O}=-0.0102 * \text { Yükseklik }(\mathrm{h})+1.5639\left(\mathrm{R}^{2}=0.98\right)
$$




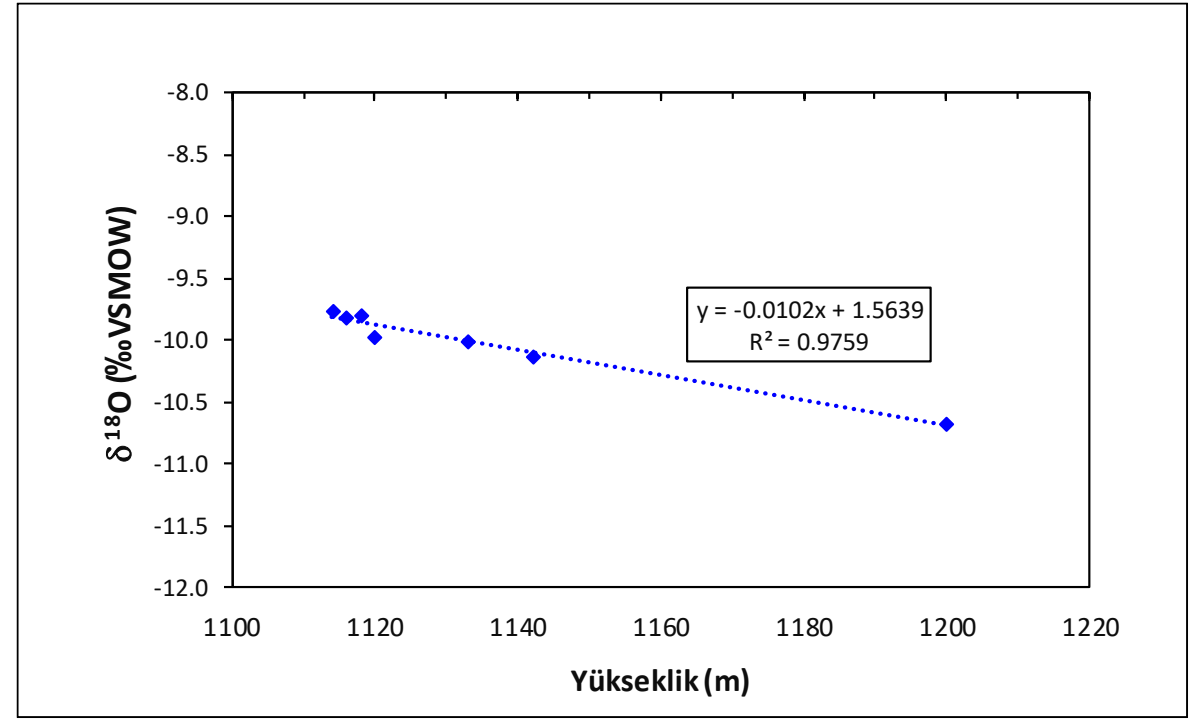

Şekil 10. Havzanın orta kesimi için yükseklik-Oksijen-18 ilișkisi (Relationship between elevation-Oxygen-18 for the middle section of the basin)

Buna göre havzanın orta kesimlerini temsil eden regresyon eșitliğine göre her 100 m' lik kot artışına bağlı olarak ${ }^{18} 0$ içeriğindeki azalmanın \%o 1.02 olduğu hesaplanmıştır (Şekil 10). Bu kaynakların ortalama beslenim alanı yükseltileri ise $1111 \mathrm{~m}$ ile $1197 \mathrm{~m}$ arasında değişmektedir.

Havzanın en yüksek yeri olan kuzeybatı bölümündeki (Hamurlubeşler ve Yukarı Homurlu) kaynak çıkışlarını temsil eden 3. grup ise E3, E4, E5, E6 ve P5 su noktaları olarak seçilmiştir. Kaynakların Oksijen-18 ile yükseltiye bağlı değişimini ifade eden regresyon eşitlikleri aşağıda verilmiştir (Eșitlik 4 ve Eşitlik 5).

$$
\begin{aligned}
& \delta^{18} \mathrm{O}=-0.0203 * \text { Yükseklik }(\mathrm{h})+15.247\left(\mathrm{R}^{2}=0.98\right. \\
& \delta^{2} \mathrm{H}=-0.0786 * \text { Yükseklik }(\mathrm{h})+22.938\left(\mathrm{R}^{2}=0.79\right)
\end{aligned}
$$

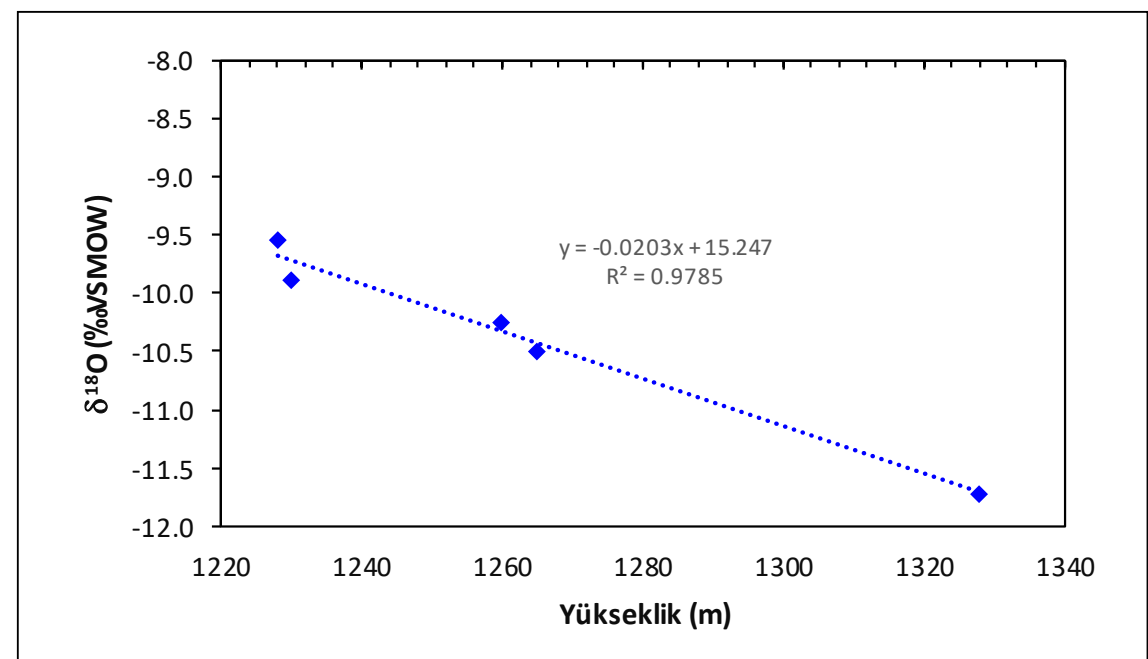

Şekil 11. Havzanın kuzeybatısı için yükseklik-Oksijen-18 ilişkisi (Relationship between elevation-Oxygen-18 for the northwestern part of the basin)

Bu örneklerin Oksijen-18 içerikleri ile yükseltiye bağlı değişimleri incelendiğinde her 100 m’ lik kot artışına bağlı olarak $\delta^{18} \mathrm{O}$ içeriğindeki azalmanın \%o 2.03 olduğu; ${ }^{2} \mathrm{H}$ içeriğindeki azalmanın ise \%o 7.86 oranında olduğu hesaplanmıştır (Şekil 11). Bu kaynakların ortalama beslenim alanı yükseltileri ise $1222 \mathrm{~m}$ ile $1327 \mathrm{~m}$ arasında değişmektedir.

Havzanın güney-güneybatı kesimindeki kaynak çıkışlarını temsil eden 4. grup ise E9, E10, E11, E13 ve M3 su noktalarıdır. Bu hattı temsil eden su kaynakları için regresyon eşitlikleri türetilmiştir (Eşitlik 6 ve Eşitlik 7).

$$
\delta^{18} \mathrm{O}=-0.0152 * \text { Yükseklik(h)+7.7682 }\left(\mathrm{R}^{2}=0.94\right)
$$


$\delta^{2} \mathrm{H}=-0.0722 *$ Yükseklik(h)+11.417 $\left(\mathrm{R}^{2}=0.81\right)$

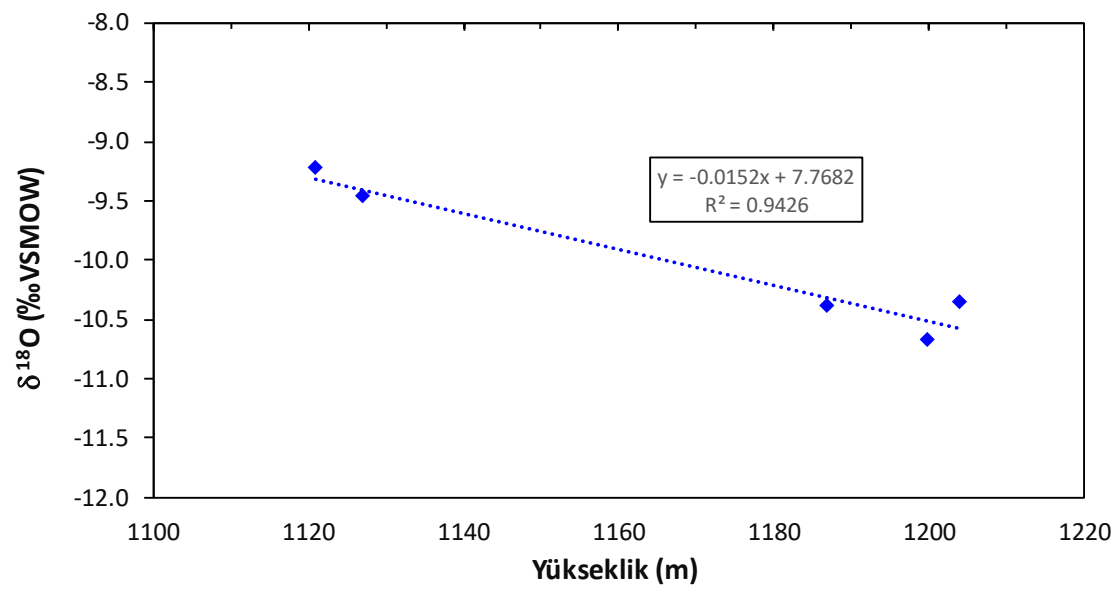

Şekil 12. Havzanın güneyi için yükseklik-Oksijen18 ilişkisi (Relationship between elevation-Oxygen-18 for the southern part of the basin)

Bu örneklerin Oksijen-18 içerikleri ile yükseltiye bağlı değişimleri incelendiğinde ise her 100 m' lik kot artışına bağlı olarak ${ }^{18} \mathrm{O}$ içeriğindeki azalmanın \%o 1.5 olduğu; ${ }^{2} \mathrm{H}$ içeriğindeki azalmanın ise \%o 7.22 oranında olduğu hesaplanmıştır (Şekil 12). Bu kaynaklar için ortalama beslenim alanı yükseltisi; havzanın güneybatısını sınırlayan Bozdağlar'ın 1119 m ile 1208 m arasında değişen yükseklikleri olarak belirlenmiştir.

\section{Sonuç ve Tartışma (Result and Discussion)}

Bu çalışmada $1447 \mathrm{~km}^{2}$ lik Seyfe Gölü sulak alanı havzasındaki su kaynaklarının duraylı izotop içerikleri incelenmiștir. Havza ölçeğinde yüzey drenaj alanı içerisinde yer alan su noktalarından 2019 Eylül ve 2019 Aralık dönemlerinde izotop örneklemeleri gerçekleştirilmiştir. Örneklenen su noktalarının havza içerisindeki izotop içeriklerinin oransal değișimi, beslenim alanı yükseltilerinin hesaplanması, farklı kökenli suların ayırtlanması ve hidrojeolojik süreçlerin açıklanmasına yönelik değerlendirmeler yapılmıştır.

Havzada yüzeyleyen jeolojik birimler suyu taşıma ve iletme özellikleri göre geçirimli, yarıgeçirimli ve geçirimsiz birimler olarak sınıflandırılmıştır. İkincil gözeneklilik kazanmış Paleozoyik yaşlı mermer birimlerin kırıklı ve çatlaklı seviyeleri akifer özelliği göstermektedir.

Duraylı izotop içeriklerine göre su örnekleri 3 farklı şekilde kümelenmişlerdir. Havzanın batısındaki Paleozoyik yaşl şiştler, kristalen kireçtaşları ve mermer birimleri temsil eden su noktaları ile kar örneklerinin çoğunluğu her iki dönemde de döteryum fazlası +15 olan doğru üzerinde dizilmişlerdir. Diğer iki meteorik doğruya göre döteryum fazlası daha yüksek olan +15 doğrusu havzanın batısını temsil etmektedir. Dolayısıyla Seyfe Gölü havzasının batı kısmını temsil eden meteorik su doğrusunun +15 döteryum fazlasıyla $\delta^{2} \mathrm{H}=8^{*} \delta^{18} \mathrm{O}+15$ şeklinde olabileceği düşünülmektedir. Bu durum havza batısının denizel kökenli yağışların etkisinde olduğunu, buharlaşmanın hızlı ve ortamdaki nem düzeyinin düşük olduğunu göstermektedir.

Havzanın batı-kuzeybatısındaki Paleozoyik metamorfik birimleri temsil eden kaynakların $\delta^{18} 0$ içerikleri, diğer su noktalarına göre daha negatif oldukları için beslenimlerinin daha yüksek kotlardan gerçekleştiği hesaplanmıştır.

Kış yağış̧arını temsil eden kar örneklemeleri, döteryum fazlası+15 olan yerel meteorik su doğrusu üzerinde, bir kısmı ise Küresel Meteorik Su Doğrusu üzerinde yer almaktadırlar. Kar yağışlarını temsil eden örneklerin Oksijen18 ve Döteryum içeriklerinin daha negatif olduğu, diğer su noktalarına göre meteorik eğrilerin alt kısımlarında kış yağışlarını temsil eden bölgede yer aldıkları görülmektedir.

DK ve Y1 su noktaları ise açık yüzeyden sürekli buharlaşma etkisi altında kalan, eğimi 5 olan buharlaşma doğrusu üzerinde kalan su noktalarıdır. DK ve Y1 örneklerinin üzerinde bulundukları buharlaşma doğrusunun eğimi ile havza yakınlarında ölçülen bağıl nem içeriği uyumlu bir ilişki göstermektedir.

Havzadaki bir grup kaynaklar ise döteryum fazlası +5 olan meteorik doğru üzerinde yer almaktadır. Düşük döteryum fazlası değerlerin havzanın gerek kurak iklim koşullarında olması; gerekse düşen yağışın tekrar tekrar 
buharlaşmaya uğraması ve ağır izotoplarca zenginleşmesi şeklinde olabileceği düşünülmektedir. Yine havzadaki bu kaynakların döteryum fazlası değerlerinin düşük olması karasal ortamda gerçekleşen yağışı oluşturan buharlaşmanın yavaş, ortamdaki nem içeriğinin ise yüksek olduğuna işaret etmektedir.

Çalışma alanındaki duraylı izotop içerikleri incelendiğinde; havzanın doğusundan batı-kuzeybatısına doğru akım yolu boyunca yükseltinin artmasıyla birlikte su noktalarının Oksijen-18 ve Döteryum içeriklerinin negatifleștiği görülmektedir.

Yeraltısularını temsil eden Yenidoğanlı bölgesindeki MT-1 ve MT-3 kuyuları ile Seyfe köyü yakınlarındaki E15 kuyusu benzer (meteorik) kökenli yağışlardan beslenen, buharlaşma etkisi görülmeyen ve Küresel Meteorik Su Doğrusu üzerinde kümelenen su noktalarıdır.

Havzanın kuzeybatısından, güneydoğusuna doğru gidildikçe her 100 metrede yükseltiye bağlı Oksijen-18 içeriğinin değiştiği belirlenmiştir. Havzanın kuzeybatısında her 100 metre için bu değer \%o 2.03, batısında \%o 0.08; havza ortalarında 1.03; güneybatısında ise \%o 1.5 olarak hesaplanmıștır.

Gerçekleștirilen çalışmada Seyfe Gölü havzasındaki hidrojeolojik süreçlerin anlaşılması ve hidrodinamik yapının kavramsallaştırılmasına yardımcı olacak duraylı izotop tekniklerinden yararlanılmıștır. Bu kapsamda kavramsallaştırma çalışmaları için hidrostratigrafik birimlerin beslenim alanları ile su noktalarının yükseltiye bağlı olarak duraylı izotop içeriklerindeki değişimlerin belirlenmesi oldukça önemlidir. Bu amaçla havzadaki su noktalarının farklı mevsimsel dönemlerde izotop içeriklerindeki değişimlerinin belirlenebilmesi için yağış, kaynak, kanal ve kuyulardan örneklemelere devam edilmesi gerekmektedir. Ayrıca havza için bu çalışma kapsamında gerçekleştirilemeyen trityum analizlerinin ileriki dönemlerde gerçekleștirilmesi planlanmaktadır. Dolayısıyla çevresel (duraylı ve duraysız) izotop içeriklerinin birlikte değerlendirilmesi ile çalışmanın geliştirilebileceği düşünülmektedir.

\section{Teșekkür (Acknowledgement)}

Çalışma yazarın doktora tez çalıșmasının bir bölümünü oluşturmaktadır. Yazar Hacettepe Üniversitesi Uluslararası Karst Uygulama ve Araştırma Merkezi Duraylı İzotop Laboratuvarında gerçekleştirilen duraylı izotop analizleri ve makale yazımı sırasındaki öneri ve görüşleri için Dr. Öğr. Üyesi Türker Kurttaş'a teşekkür eder. Ayrıca makale metninin son halini almasındaki katkılarından dolayı editör ve hakemlere teșekkür eder.

\section{Çıkar Çatışması (Conflict of Interest)}

Yazar tarafından herhangi bir çıkar çatışması beyan edilmemiştir. No conflict of interest was declared by the author.

\section{Kaynaklar (References)}

Bershaw, J., 2018. Controls on Deuterium Excess across Asia. Geosciences, 8, (7), 257.

Clark, I., Fritz, P., 1997. Environmental Isotopes in Hydrogeology. Second Edition, Lewis Publisher.

Craig, H., 1961. Isotopic Variations in Meteoric Waters. Science, 133, 1702-1703.

Çelik, M., Ünsal, N., Tüfenkçi, O., Bolat, S., 2008. Assessment of Water Quality and Pollution of the Lake Seyfe basin, Kırșehir, Turkey. Environmental Geology, (55), 559-569.

Çiftçi, E., 2013. Seyfe Gölü Havzası'nda (Kırşehir) Doğal Ortam-Yeraltısuyu ilişkisi, Yüksek Lisans Tezi, Fırat Üniversitesi, Elazığ. Dansgaard, W., 1964. Stable Isotopes in Precipitation. Tellus, 16, 436- 469.

Delattre, H., Vallet-Coulomb, C., and Sonzogni, C., 2015. Deuterium Excess in the Atmospheric Water Vapour of a Mediterranean Coastal Wetland: Regional vs. Local Signatures. Atmospheric Chemistry and Physics, 15, 10167-10181.

DSİ., 1975. Kırşehir Seyfe Ovası Planlama Kademesi Jeofizik Rezistivite Etüd Raporu. Jeoteknik Hizmetler ve Yeraltı Suları Dairesi Başkanlı̆̆ı, Ankara.

DSİ., 1979. Kırşehir Seyfe Ovası Hidrojeolojik Etüt Raporu. Jeoteknik Hizmetler ve Yeraltı Suları Dairesi Başkanlığı, Ankara.

DSİ., 2004. Seyfe Ovası Hidrojeolojik Revize Etüt Raporu. Jeoteknik Hizmetler ve Yeraltı Suları Dairesi Başkanlığı, Ankara.

Erguvanlı, K., 1957. Kırşehir Kuzeyinde Seyfe Ovasının Hidrojeolojik Etüd Raporu. Jeoteknik Hizmetler ve Yeraltı Suları Dairesi Başkanlığı, Ankara.

Froehlich, K., Gibson, J., Aggarwal, P., 2002. Deuterium Excess in Precipitation and its Climatological Significance. Journal of Geophysical Research, Atmospheres, 23p.

Gat, J. R., Gonfiantini, R., 1981. Stable Isotope Hydrology. Deuterium and Oxygen-18 in the Water Cycle. IAEA, Techical Report Series No. 210, 337pp. Alba, E., Dorronsoro, B., 2005. The Exploration/Exploitation Tradeoff in Dynamic Cellular Genetic Algorithms. IEEE, Transactions on Evolutionary Computation, (9), 26-142.

Gat, J.R., Bowser, C.J., Kendall, C., 1994. The Contribution of Evaporation from the Great Lakes to the Continental Atmosphere: Estimate Based on Stable Isotope Data. Geophysical Research Letter, 21, (7), 557-560. 
Gat J.R., 2005. Some Classical Concepts of Isotope Hydrology. In: Aggarwal P.K., Gat J.R., Froehlich K.F. (eds) Isotopes in the Water Cycle. Springer, Dordrecht.

Kıymaz, S., Asar, M., Güneş, V., 2011. Standartlaştırılmış Yağış İndeksi ile Seyfe Gölü’nün Kuraklık Dönemlerinin Belirlenmesi, Gaziosmanpaşa Üniversitesi Ziraat Fakültesi Dergisi, 91-102.

Kıymaz, S., Karadavut, U., 2014. Seyfe Gölü Havzasında Yer Alan Kuyuların Sularının Sulama Suyu Kalitesi Açısından Değerlendirilmesi. Uludağ Üniversitesi Ziraat Fakültesi Dergisi, Cilt 30, Sayı 1, 21-31.

MTA., 1991. 1/100000 Ölçekli Açınsama Nitelikli Türkiye Jeoloji Haritaları Serisi No: 34 Kırșehir G-18 Paftası ve açılaması Ankara, Türkiye, $12 \mathrm{~s}$

MTA., 1992. 1/100000 Ölçekli Açınsama Nitelikli Türkiye Jeoloji Haritaları Serisi No:34 Yozgat G-19 Paftası ve açıklaması, Ankara, Türkiye, $16 \mathrm{~s}$

MTA., 2009. Kırşehir-Mucur-Seyfe Gölü Havzası Maden Jeolojisi Raporu. Ankara.

Önhon, E., 1969. Seyfe Ovası Kristalize Kalker Sahasının Karst Etüdü ve Seyfe Kaynağının Geliștirilmesi Raporu. Jeoteknik Hizmetler ve Yeraltı Suları Dairesi Bașkanlığı, Ankara.

Peng, H., B. Mayer., S. Harris., H. Krouse., 2007. The Influence of Below-Cloud Secondary Effects on the Stable Isotope Composition of Hydrogen and Oxygen in Precipitation at Calgary, Alberta, Canada. Tellus, 59B, 698-704.

Salamalikis, V., A. A. Argiriou., E. Dotsika., 2016. Isotopic Modeling of the Sub-Cloud Evaporation Effect in Precipitation. Science of the Total Environment, 544, 1059-1072.

Sayhan, H., 2000. Seyfe Havzasının Jeomorfolojisi (Kırșehir). Gazi Üniversitesi Kırșehir Eğitim Fakültesi Dergisi, Sayı 1, 1-12.

Sayhan, H., 2001. Seyfe Gölü Eski Seviyelerinin Kuvaterner Jeomorfolojisi Açısından Etüdü. Gazi Üniversitesi Kırşehir Eğitim Fakültesi Dergisi, Cilt 2, Sayı 2, 55-73.

Seymen, İ., 1982. Kaman dolayında Kırşehir masifinin jeolojisi. Doçentlik Tezi, İstanbul Teknik Üniversitesi, İstanbul.

Tüfenkçi, 0.0., 2005. Seyfe Kaynağı ve Dolayının (Kırşehir) Hidrojeoloji incelemesi. Yüksek Lisans Tezi, Ankara Üniversitesi, Ankara.

Ünsal, N., 1999. Seyfe Ovası Kaynaklarının Kimyasal ve İzotopik Bileșenleri ve Kökeni. Gazi Üniversitesi Fen Bilimleri Enstitüsü Dergisi, 295-308.

Yılmaz, H.M., Reis, S., 2008. Seyfe Gölü'nün Zamansal Değişiminin Uzaktan Algılama Tekniği ile İzlenmesi. Hydrological Processes, 448-4454.

Yiğitbașığlu, H., 1993. Seyfe Gölü ve Çevresinin Jeomorfolojisi. Doktora Tezi, Ankara Üniversitesi, Ankara. 